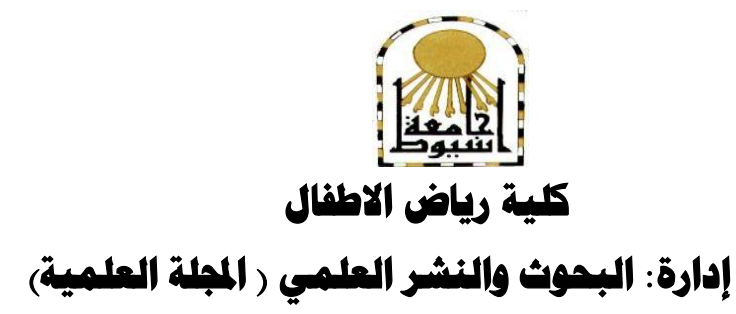

$=====$

\title{
فاعلية أنشطة البراعم في ثمقيق نواتج التعلم المتوقعة وتنمية المسنولية الاجتماعية لأطفال الروضة
}

$$
110 \mid
$$

| - ا.د./ شهناز هممد عبد|لاله

أستاذ الصحة النفسية المتفرع

قسم العلوم النفسية

$$
\text { كلية رياض الأطفال - جامعة أسيوط }
$$

أستاذ مناهج الطقل المساعد

ووكيل كلية رياض الأطفال للاراسات العليا والبحوث

$$
\text { جامعة أسيوط }
$$

أ./ رضية جمال علي هصطفى جامعه لميوط

موجه رياض أطفال بإدارة أبنوب التعليمية

لنيل درجة الماجستير في التربية تخصص " تربية الطقل"

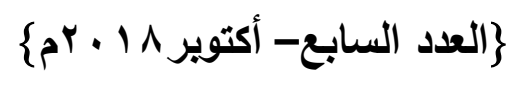




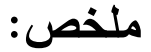

هدف الاراسة: تحقيق نواتج التعلم المتوقعة وتتمية المسئولية الاجتماعية لأطفال الروضة مجموعة الدراسة: اقتصرت مجموعة الدراسة الحالية على مجموعة مكونة من ( • 1 (1) طفلا

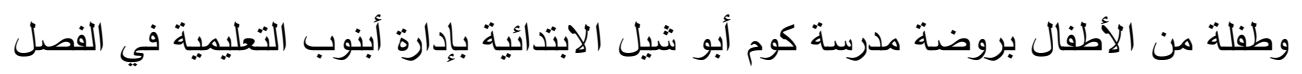

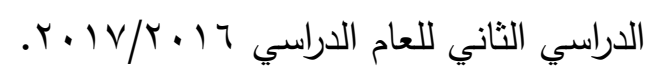

أدوات الدراسة: لتحقيق هدف الدراسة نم إعداد الأدوات التالية :

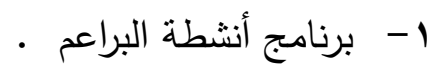

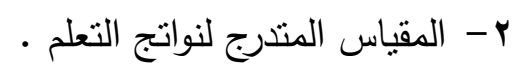

r- مقياس المسئولية الاجتماعية المصور لطفل الروضة .

ع - مقياس المسئولية الاجتماعية لطفل الروضة مقدم لمعلمة الروضة . ه- مقياس المسئولية الاجتماعية لطفل الروضة مقدم لولي الأمر •

نتائج الاراسة:

توصلت الدراسة إلى وجود فروق ذات دلالة إحصائية بين رثب متوسطي درجات

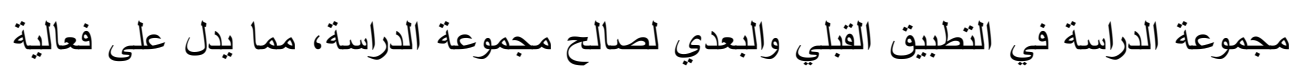

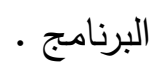

الكلمات المفتاحية : أنشطة البراعم - نواتج التعلم - المسئولية الإجتماعية - طفل الروضة . 
ا.د./ شهناز محمد عبدالله

فاعلية أنشطة البراعم في تحقيق نواتج

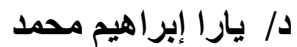

التعلم المتوقعة وتتمية المسئولية الاجتماعية التئية

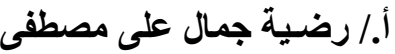

لأطفال الروضة ونميه

\title{
The Effectiveness of Buds Activities
}

(Kinder garten scouts) in Achieving the Expected Learning Outcomes and

Developming The social Responsibility for kindergartners

\begin{abstract}
Study Aims: Achieve expected learning outcomes and develop social responsibility for kindergarten children.

Study Group: The current study group was limited to a group of (160) children and children in the Koum Abu Shail primary school in the Department of Education Abnob in the second semester of the academic year 2016/2017.
\end{abstract}

Study Tools: To achieve the objective of the study, the following tools were prepared:

1- Program of the activities of buds.

2- Graduated scale of learning outcomes.

3- Measure the social responsibility of the visual child kindergarten.

4- The social responsibility measure for the preschool child is presented to the kindergarten teacher.

5- The social responsibility measure of the kindergarten child submitted to the guardian

Study results: The study found that there were statistically significant differences between the intermediate grades of the study group in the tribal and remote application in favor of the study group, which indicates the effectiveness of the program.

Key words: Buds - Learning outcomes - Social responsibility Kindergarten child 


\section{مقدمـة:}

تُعتبر مرحلة الطفولة هي المرحلة الذهبية في حياة الإنسان لأن ما يتعلمه الطفل

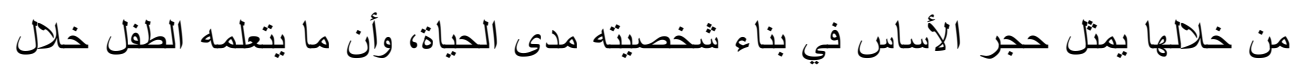
هذه المرحلة وخاصة سنواته الخمس الأولى يعادل إلى حد كبير ما يتعلمه خلال بقية حياته، ويذهب البعض إلى أن هناك بعضًا من جوانب شخصية الطفل إذا لم تتمو خلال هذه الأن

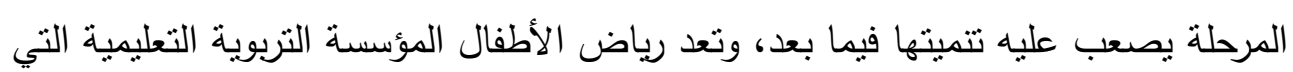

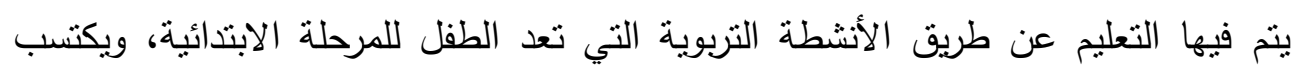

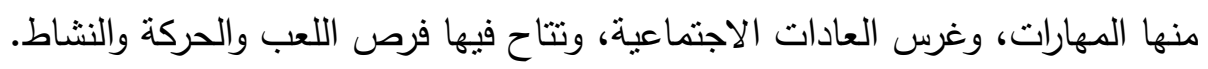
إن أهداف مرحلة رياض الأطفال ترتكز في إمتاع الأطفال في جو من الحرية

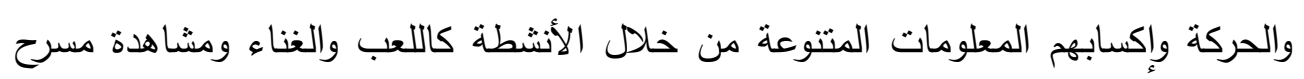
العرائس كما تتمي القيم والآداب والسلوك المرغوب مع تتمية التقة بالنفس الاتنماء لديهم،

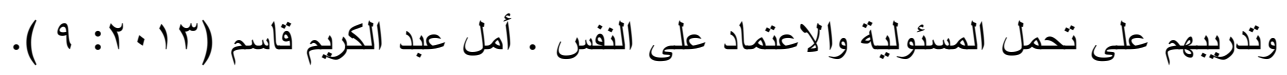

وبما أنه من ضمن الأسباب المهمة لتتمية المسئولية الاجتماعية لدى الأطفال هي

تدريب قدرة الأبناء على تحمل المسئولية وهي تعد أحد أهم مصادر الصحة النفسية، فكلما

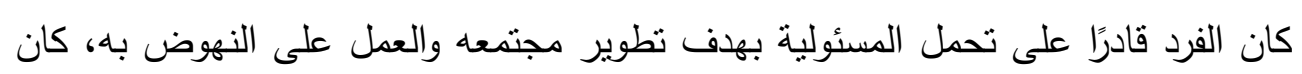

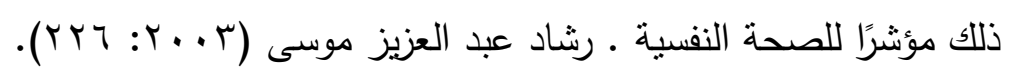

وذكر أن الهُف في التربية المصرية المعاصرة يتمتل في إيجاد المواطن الواعي

بأوضاع وطنه من النواحي السياسية والاقتصادية والاجتماعية والفكرية والتربوية؛ ليصبح

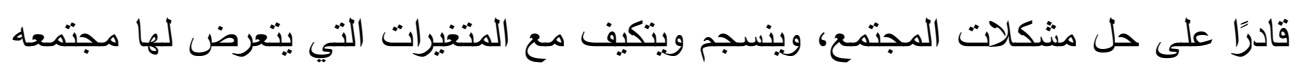
وعالمه، وتعميق فكرة الوطنية والقومية لديه، وتتمية إحساسه بالمسئولية الإجتماعية

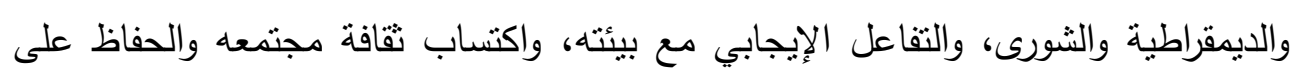

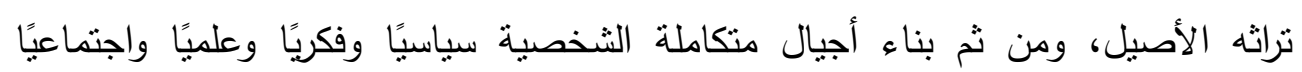

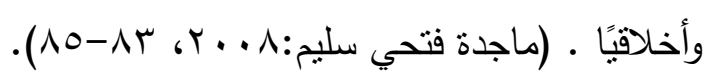


1.د./ شهناز محمد عبدالله

دار يارا إبراهيم محمد

فاعلية أنثطة البراعم في تحقيق نواتج التعلم المتوقعة وتنمية المسئولية الاجتماعية

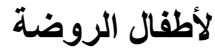

وحيث أنه يولد الطفل ولديه استعداد فطري لاكتساب وتعلم المسئولية، فالطفل يتعلم

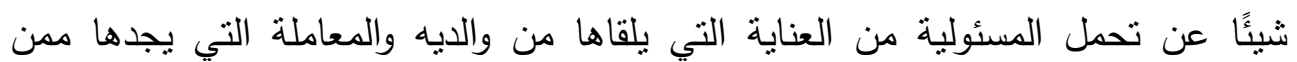
يتعاملون معه، فإذا توافرت الظروف المناسبة للطفل للقيام بدور محدد في الجماعة ينمو

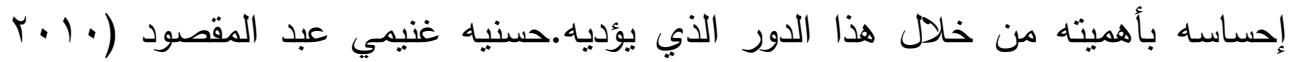
$(19-10$ :

وقد أصبحت المسئولية الاجتماعية ركيزة مهمة من ركائز التربية الحديثة على إعتبار أن اكتساب الثخصية لها يدخل في نسيج ما تكونه من اتجاهات وتقوم به من من رهن أداءات وسلوكيات في المواقف الاجتماعية المختلفة وهي تتعكس على العلاقات بالآخرين، وهي أيضا تجعل الطفل معنيًا بما يدور حوله فاعلًا في هذا العالم ومؤثرًا فيه، إذ يتعود تدريجيا تحمل المسئولية، وتتمو لديه الثقة بالنفس كما أنها تجعل الطفل قادرًا على ضبط هيط السلوك والقيام بالأدوار المختلفة وتتمية مقومات التواصل لديه مما يمكنه من دخول الحياة الاجتماعية من بابها الواسع واثقًا من نفسه متفائلًا نشطًا في دوره وباحثًا عن تحديد مكانته.

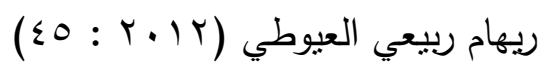

فقد إتفقت عزة عبد الرحيم مع مختار الكيلاني في أن موضوع المسئولية

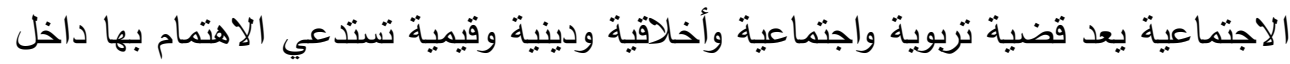
الكيان الاجتماعي عامة لما ينطوي عليها من دلالات قيمة لعياة الإنسان.

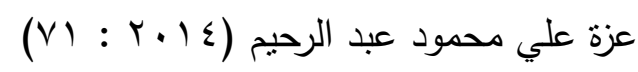

ويمكن القول أن المسئولية الاجتماعية تعد أحد الدعائم الأساسية التي تقوم عليها

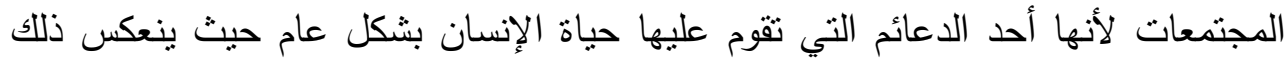
بدوره على التتمية وظهور معالمها التي ترتبط بوجود المسئولية الاجتماعية جنبًا إلى جنب لهنب في المجتمعات المتقدمة التي تسعى دائمًا إلى التقدم. هشام نبيل عبد الرؤف عبد العزيز $(O V: r . I T)$ 


\section{المجلة العلمية لكلية رياض الاطفال - جامعة اسيوط}

ومن هنا أصبح وجود برامج لتتمية المسئولية الإجتماعية مطلبًا ضروريًا ومهمًا ولابد من الإهتمام والتركيز عليها في العملية التعليمية الحالية، ولكي يتم تتمية المسئولية الإجتماعية

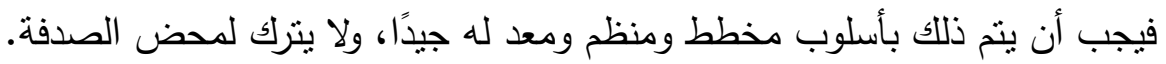
وجاء في وثيقة المعايير القومية لرياض الأطفال (^ . . ץ) لوزارة التربية والتعليم من

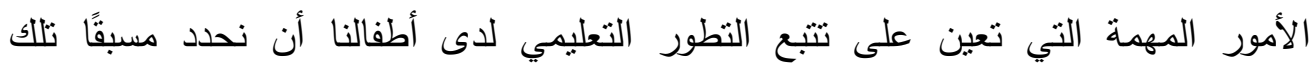
المواصفات والخصائص التي نتوقع أن يكتمل نكوينها لدى الطفل من مرحلة رياض الأطفال

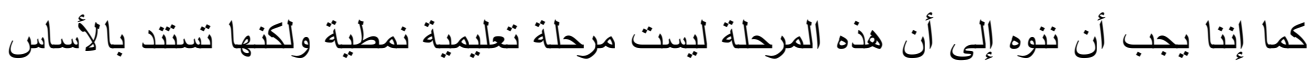

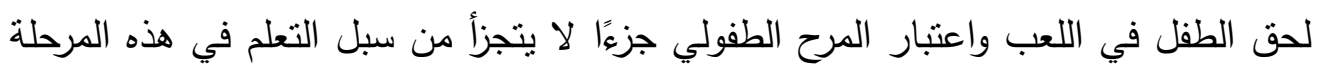

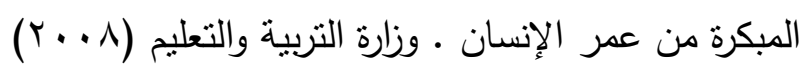
وحيث إن المعايير القومية لرياض الأطفال ^ ـ. . ب كانت امتدادا للمعايير القومية في مصر والتي صدرت وثثقتها في عام r . . r مما يؤسس صدورها عهد جديد ينت فيه التعامل مع قضايا التعليم في رياض الأطفال من منظور إستراتيجي بركز على الجودة والمحاسبية.

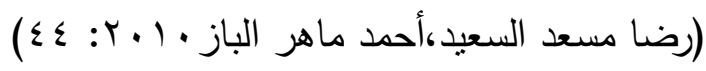

وبما أن وزارة التربية والتعليم تهدف إلي تحقيق النمو الأمثل للنشء في جميع النواحي بما بكفل تكوين الثخصية المتزنة المتكاملة حيث إن الأهداف التي تسعي إليها الأنشطة

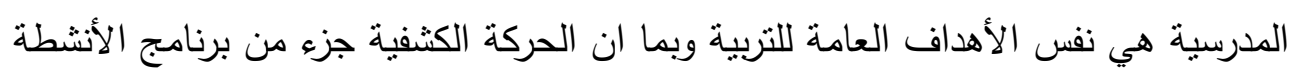

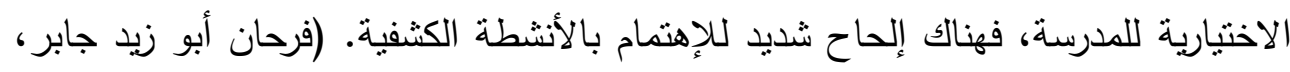
$(1:$ : . . E

فإن الحركة الكثفية تميزت في تأهيل الكثافين بتأصيل روح الانتماء، ونبتها حتى

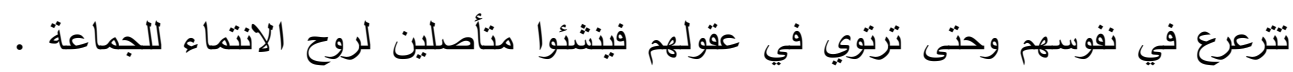

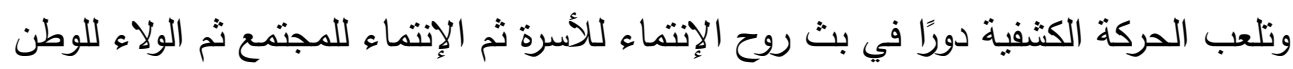
وهو هدف من أهداف الحركة الكثفية في تهذيب أفرادها ليكونوا خير بنية للوطن وخير الإنياء

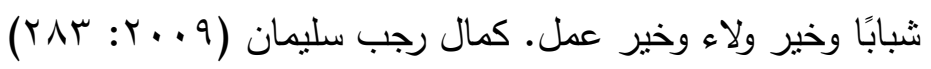


وتعد مرحلة البراعم مرحلة مستحدثة في مجال الحركة الكثفية، حيث تم تقسيم

مراحل الكثافة إلى أربع مراحل هي (الأثبال -الكثاف-الكثاف المتقدم- الجوال ) تنبدأ

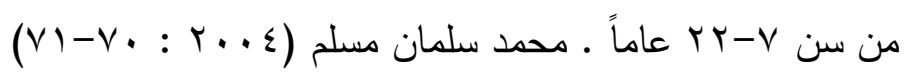

والطريقة الكثفية تقوم على وعد وقانون وشعار وتحية وجميع هذه العناصر يوجد

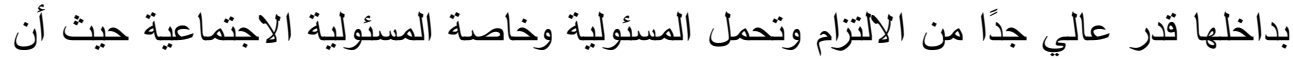
الوعد يحمل مسئوليات متعددة (تجاه الله - تجاه الآخرين - تجاه الذات) وهي نفس المبادئ

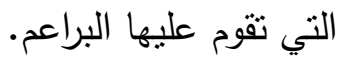

وعندما بدأت مرحلة البراعم كانت لأطفال الصف الأول والثاني من التعليم الأساسي (Y-7) سنوات، وتم إستحداثها من الجمعيات العاملة في مجال الكثافة والمرشدات.

ويعد أن نجحت فكرة البراعم وتم تكوين فرق من البراعم بالسنة الأولي من التعليم

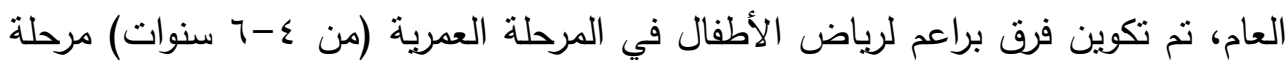
رياض الأطفال، وكانت محافظة أسيوط هي أولى المحافظات التي تم فيها تكوين فرق براعم

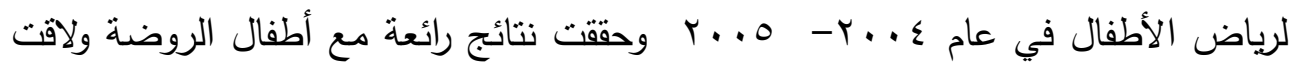
قبولًا من المعلمات وأولياء الأمور، وتبعا لهذا النجاح الذي تحقق مع الأطفال وظهر في

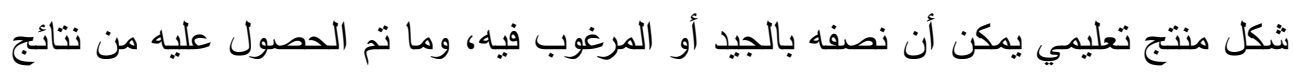
تربوية عالية تظهر على الأطفال (نواتج التعلم).

وبناءً على ما سبق فإننا نرى إنه يمكن إستثمار مرحلة البراعم في تتمية جوانب

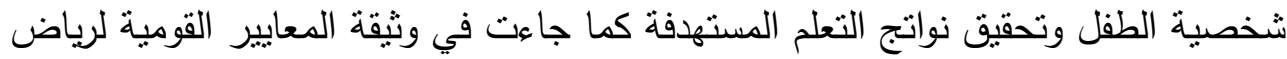

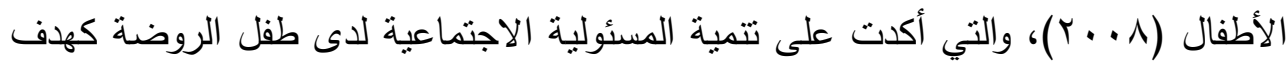
أساسي للتربية، وذلك لتتشئة المواطن الواعي بأوضاع وطنه، والقادر على تحمل المسئولية

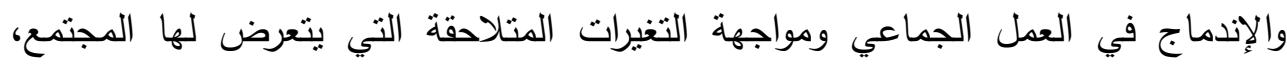
والإلزام الخلقي والديني نحو الجماعة والمجتمع. 
مشكلة الاراسة:

بدأ الإحساس بمشكلة الدراسة من خلال العمل الميداني للباحثة (موجه رياض

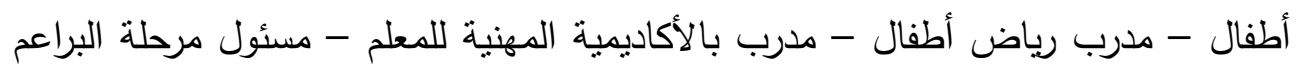

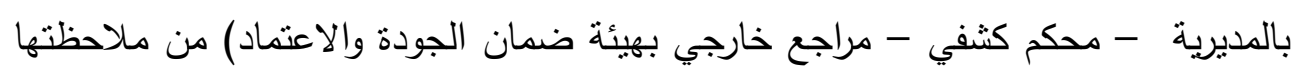

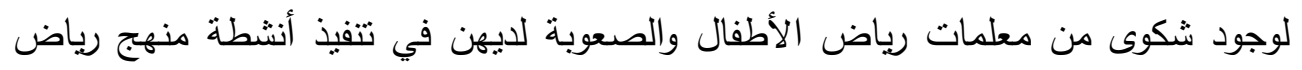

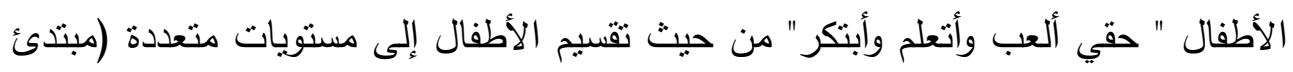

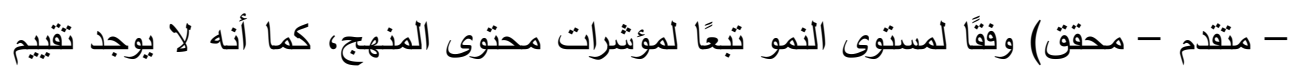

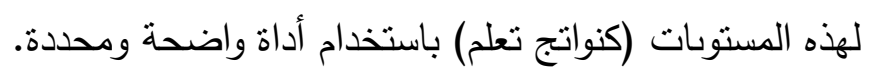

وحيث أن المعايير القومية لرياض الأطفال انتملت على العديد من أدوات القياس

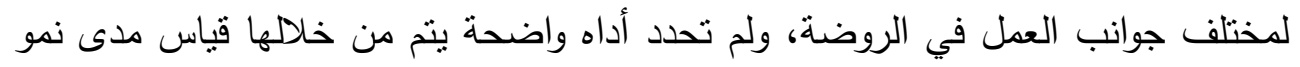
الطفل ومدى تحقيق التقدم في أدائه (كناتج تعلم) مقارنة بمجالات المعايير الأخرى. وكنلك انبيقت مشكلة الدراسة الحالية من خلال ما يلي: 1- الإطلاع على بعض الأدبيات والبحوث والدراسات السابقة التي تناولت أهمية الأنشطة

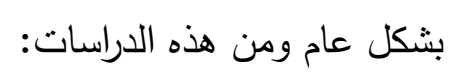

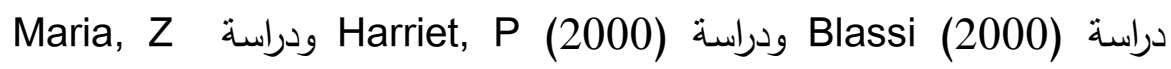

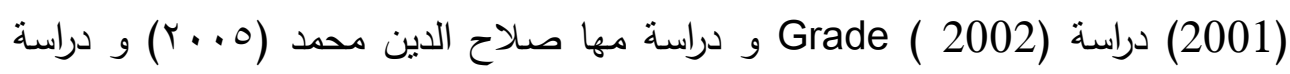

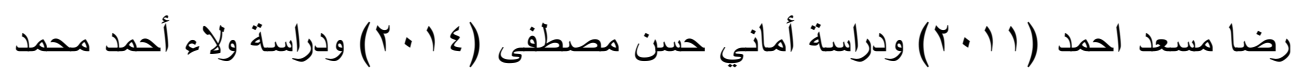

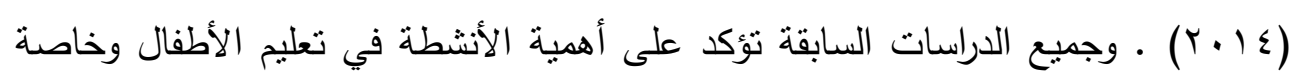

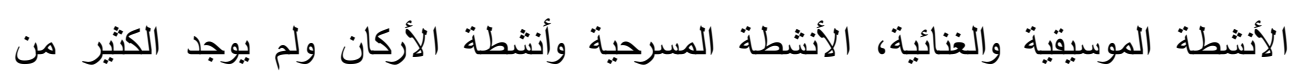
الأنشطة التي تهتم بربط الطفل بالبيئة والمجتمع المحيط.

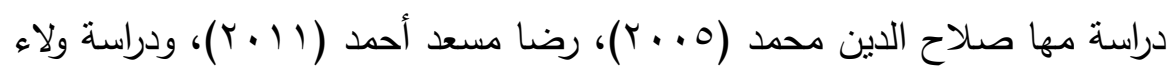

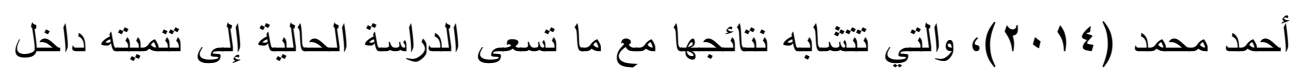

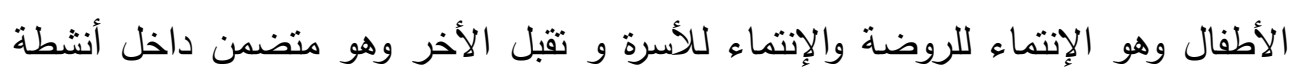

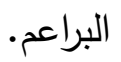


1.د./ شهناز محمد عبدالله

د/ يارا إبراهيم محمد

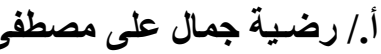

فاعلية أنشطة البراعم في تحقيق نواتج التعلم المتوقعة وتنمية المسئولية الاجتماعية

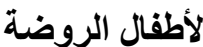

r - الإطلاع على بعض الأدبيات والبحوث والدراسات السابقة التي تتاولت أهمية الأنشطة

$$
\text { البراعم والكثافة ومن هذه الدراسات : }
$$

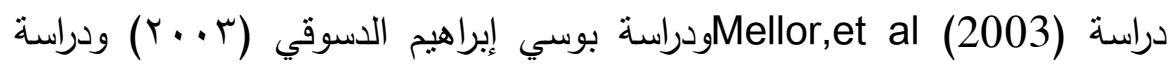
Galton,M.(2004)

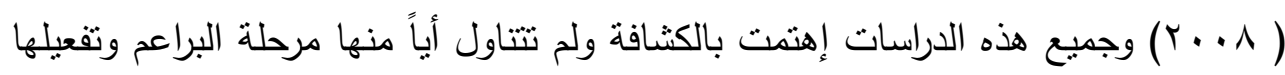

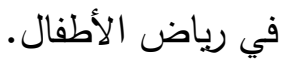

ץ- - الإطلاع على بعض الأدبيات والبحوث والدراسات السابقة التي تتاولت نواتج التعلم

$$
\text { ومن هذه الدراسات: }
$$

وجدت الباحثة كثرة الدراسات التي تتاولت تفعيل نواتج تعلم رياض الأطفال

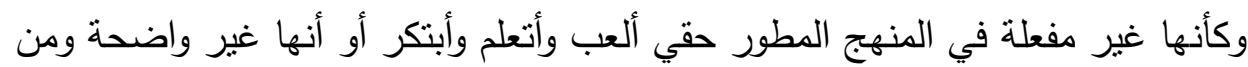

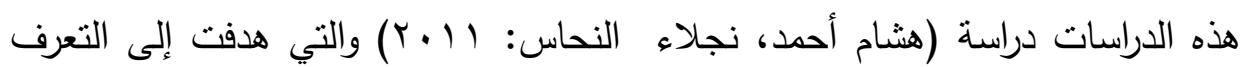
على فاعلية برنامج أنشطة مقترح قائم على الخبرة المتكاملة لإكساب أطفال الروضة الرها المفاهيم الجغرافية الأساسية في المنهج المطور لرياض الأطفال، دراسة (مرفت مدني:

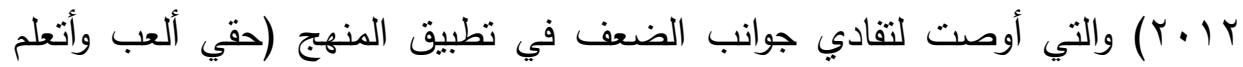
وأبتكر) أوصت بمجموعه من الأنشطة التي تساعد في تتمية الوعي السياسي لطفل

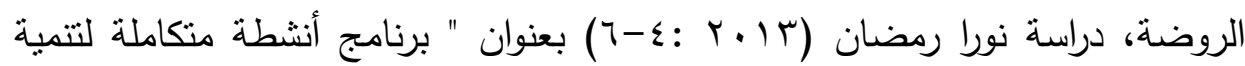

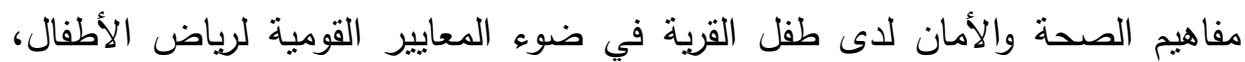

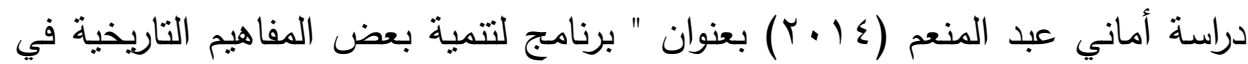

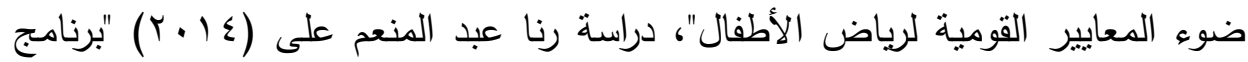

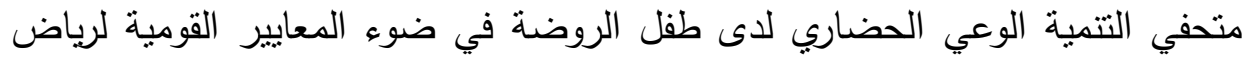

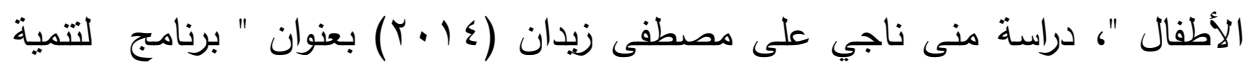
التسامح لدى أطفال الروضة في ضوء المعايير القومية لرياض الأطفال " وتتاولت تفعيل

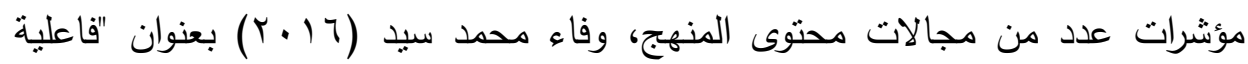

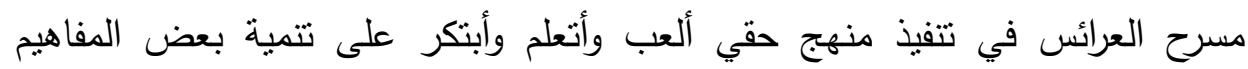
الاجتماعية والقيم الأخلاقية لدى طفل الروضة ". 


\section{المجلة العلمية لكلية رياض الاطفال - جامعة اسيوط}

ـ - الإطلاع على بعض الأدبيات والبحوث والدراسات السابقة التي تتاولت أهمية المسئولية الإجتماعية ومن هذه الدراسات :

دراسة Dic riely (2000) Dوالتي هدفت إلى تدريس قيم المواطنة والمسئولية

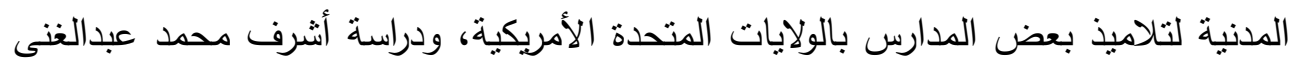

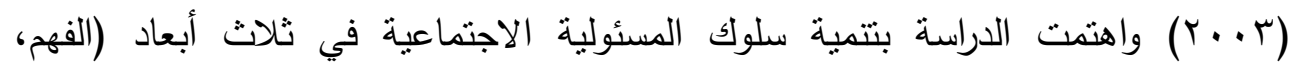

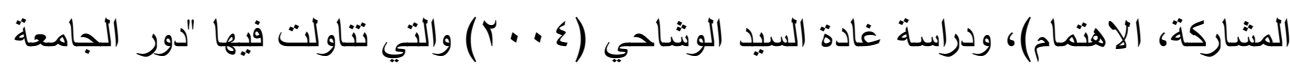
في تتمية المسئولية الاجتماعية لدى طلابها، دراسة (2008) Kim والتي هدفت إلى معرفة "فاعلية برنامج إرشادي في تتمية المسئولية الاجتماعية لدى أطفال المدارس الابتدائية فى دلى الاجيه

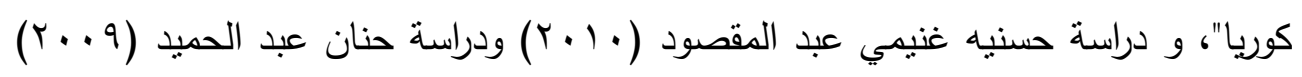
وهدفت الدراسة إلى الكثف عن فاعلية البرنامج في تتمية المسئولية الاجتماعية لدى أطفال

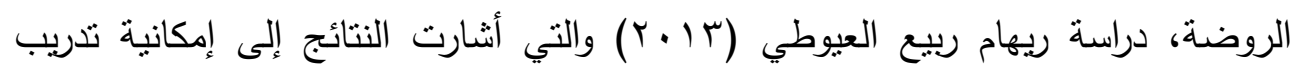

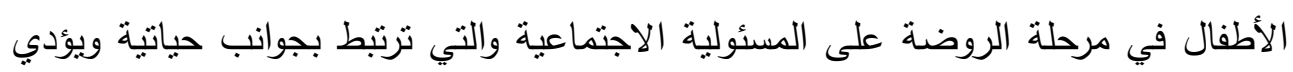

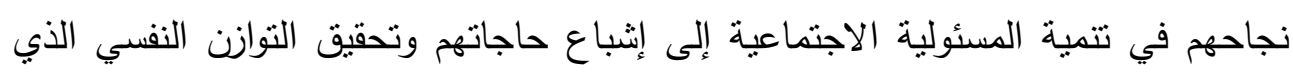

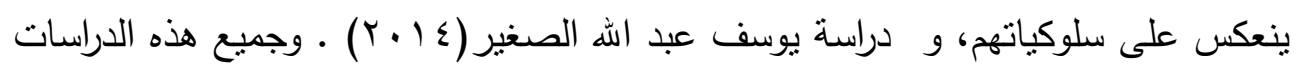
تشير وتؤكد على أهية تتمية المسئولية الاجتماعية لدى طفل الروضة وفئ وفي سن مبكرة. ه- - وبناءً على ما تقدم وما كثفت عنه نتائج تطبيق الاستبيان الخاص بنشاط البراعم بالروضة

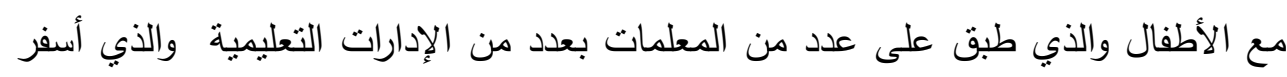

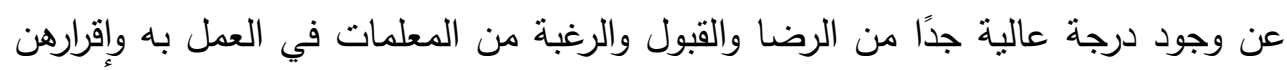

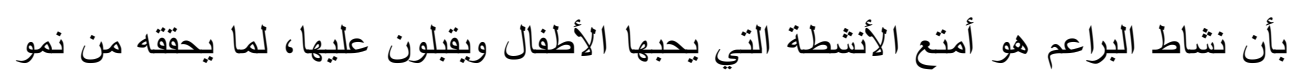
واضح على الطفل من جميع الجوانب، كما أنه بلقى قبولاً وترحيبًا من ولي الأمر . وقد نم عمل استطلاع رأي عدد من معلمات رياض الأطفال على مستوى عدد

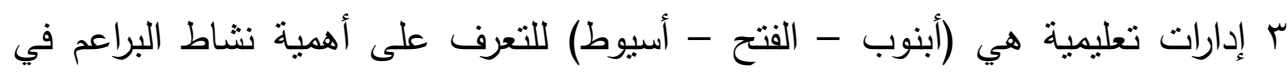

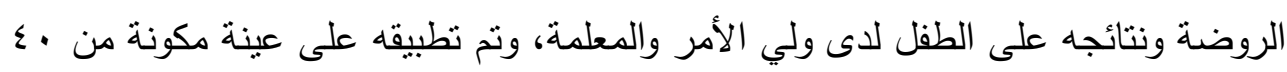

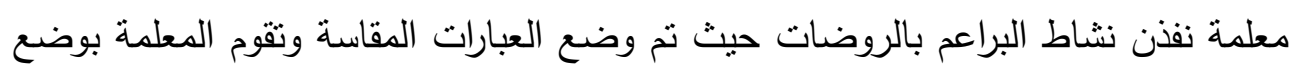
العلامة التي ترى إنها مناسبة من وجهة نظرها من خلال وجود عدد من الخيارات هي بي 
ا.د./ شهناز محمد عبدالله

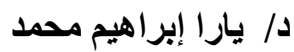

فاعلية أنشطة البراعم في تحقيق نواتج

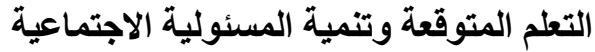

لأطفال الروضة ونئة

(نعم)، (أحيانا) (لا)، وتم تصحيح استطلاع الرأي بمفتاح تصحيح (ץ-1- (.) فكانت نسب الموافقة على نشاط البراعم هي كالتالي:

\begin{tabular}{|c|c|c|}
\hline نسبة الإجابة ب ( نعم ) على البعد & 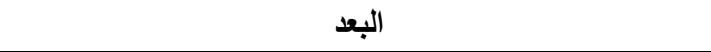 & P \\
\hline 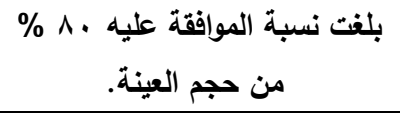 & البعد الأول: جاذبية نشاط البراعم والإقبال عليه. & 1 \\
\hline 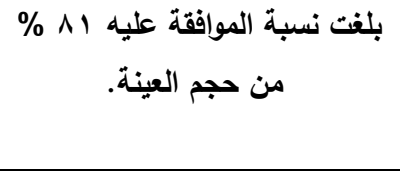 & 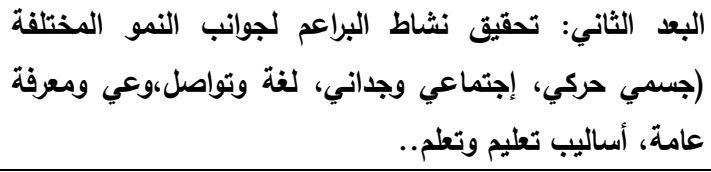 & r \\
\hline بلغت نسبة الموافقة عليه & والإنفعالية. الثالث: علاج نشاط البراعم لبعض المشكلات السلوكية & $r$ \\
\hline بلغت نسبة الموافقة عليه ب9\% من مجم العينة. & والبعد الرابع: ربط الطقل بالبيئة والحياة اليومية. & $\varepsilon$ \\
\hline 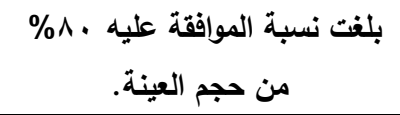 & البعد الخامس: إثباع بعض الحاجات النفسية لطقل الروضة. & $\bullet$ \\
\hline
\end{tabular}

ونلاحظ في هذا الجدول إرتفاع نسب الموافقة على الاستبيان حيث جاء البعد الأول والخامس بنسبة موافقة بلغت ، ^\% من حجم عينة الاستطلاع وهي نسبة عالية جدًا، أما البعد الثاني والثالث فبلغت نسبة الموافقة عليه 1^/ من حجم العينة وهي مرتفعة أما البعد الرابع فكان الأكثر ارتفاعًا في نسب الموافقة حيث بلغت نسبة الموافقة بو\%.

لذلك تسعى الدراسة الحالية إلى تتفيذ نشاط البراعم مع أطفال الروضة تتفذه المعلمات (من خلال برنامج) للتعرف على مدى إمكانية تحقيق نواتج التعلم لطفل الروضة كما حددنها وزارة التربية والتعليم.

ومما سبق تتحدد مشكلة الدراسة في وجود صعوبات لدى معلمات رياض الأطفال في تتفيذ منهج " حقي ألعب وأتعلم وأبنكر " وتدني تحقق النتائج المرجوة منه بالطرق التقليدية . 


\section{وقد حاولت الاراسة الحالية الإجابة على الأسئلة التالية :}

- - إلى أي مدى يمكن أن بسهم برنامج أنشطة البراعم في تحقيق نواتج التعلم المنوقعة

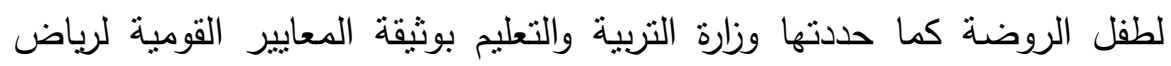

\section{الأطفال؟}

- - إلى أي مدى يمكن أن يسهم برنامج أنثطة البراعم في تتمية المسئولية الاجتماعية لطفل الروضة؟ اي مدى

\section{أهداف الاراسة : n}

\section{تهوف الدراسة الحالية إلى :}

$$
\text { - - تقديم برنامج كثفي (البراعم) في مرحلة رياض الأطفال. }
$$

- - قياس فاعلية البرنامج المقترح في تحقيق نواتج التعلم المتوقعة لطفل الروضة كما حدنها وزارة التربية والتعليم.

- - قياس فاعلية البرنامج المقترح في تتمية المسئولية الاجتماعية لطفل الروضة.

\section{أهمية الدراسة :}

- أتبع أهمية الدراسة الحالية من أهمية مرحلة الطفولة المبكرة وتأثيرها الكبير

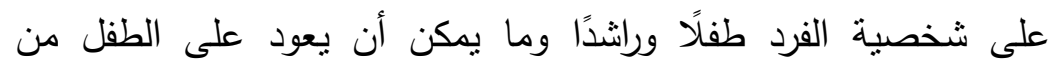

أداءات نشكل فكره وشخصيته من خلال ما يقدم له من معارف ومهارات.

r- صدور المعايير القومية لرياض الأطفال والإهنمامات المتزايدة من قبل

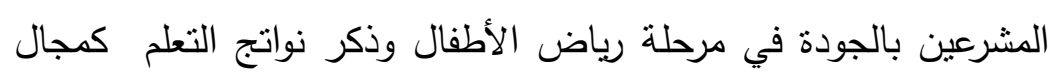

$$
\text { رئيسي(أول مجال ) من مجالات المعايير القومية لرياض الأطفال. }
$$

r- تعتبر الدراسة الحالية حلقة في سلسلة الدراسات العربية القليلة التي تعنى

$$
\text { بتتمية المسئولية الإجنماعية لاى طفل الروضة. }
$$

ع - أهمية المسئولية الإجتماعية لبقاء واستمرار المجتمع. 
1.د. - شهناز محمد عبدالله

د/ يارا إبراهيم محمد مديد

أ. أرضية جمال على مصطفى إير همث
فاعلية أنثطة البراعم في تحقيق نواتج التجاع التعلم المتوقعة وتنمية المسئولية الاجتماعية

ه- حداثة الدراسات في مجال الأنشطة الكثفية في رياض الأطفال بصفة خاصة وفي الميدان التربوي بصفة عامة.

צ- تطبيق منهج رياض الأطفال الجديد (حقي ألعب وأتعلم وأبتكر) والتغيرات التي طرأت على أداء المعلمة لدورها التربوي وما ترتب على ذلى ذلك من

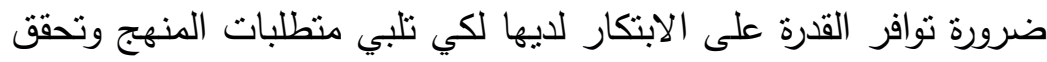

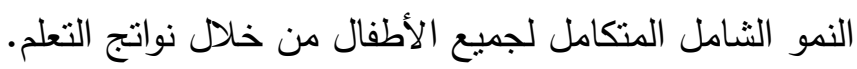
- V تقديم برنامج جديد في التعلم قائم على أنشطة البراعم في رياض الأطفال

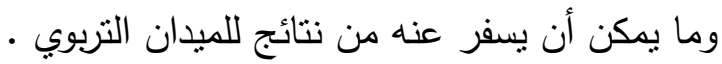

حدود الدراسة : تحدد الدراسة الحالية بـ:-

- الحدود البشرية : حيث تكونت عينة الدراسة الحالية من (.7 (1) طفل وطفلة من

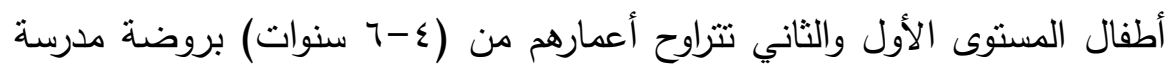
كوم أبو شيل الابتدائية إدارة أبنوب التعليمية - محافظة أسيوط للعام الدراسي . r. IV-r.17

- - الحدود الزمنية : الفصل الدراسي الثاني من شهر فبراير وحتى مايو V V. م م. - - الحدود المكانية : نم تطبيق البحث على عينة ممثلة من أطفال روضة مدرسة كوم

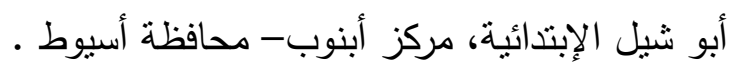
- - الدود الموضوعية : اقتصرت حدود الدراسة الموضوعية على: •برنامج أنشطة البراعم (الكثافة).

المسئولية الإجتماعية وإقتصرت على الأبعاد التالية (الإعتماد على النفس-

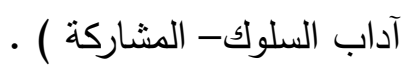


بعض نواتج التعلم المنوقعة لطفل الروضة كما حددتها وزارة التربية والتعليم

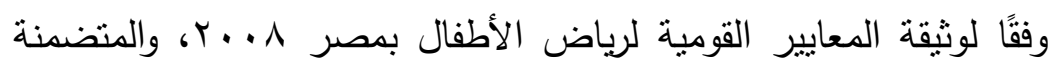

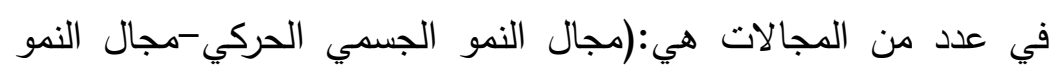

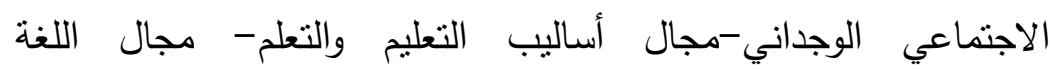
والتواصل- مجال الوعي والمعرفة العامة).

\section{أدوات الدراسة:}

$$
\text { تم إعداد الأدوات التالية: }
$$

Y - مقياس المسئولية الإجتماعية المصور لطفل الروضة.

r- المقياس المتدرج لنواتج تعلم طفل الروضة .

\section{مصطلحات الاراسة : مصات}

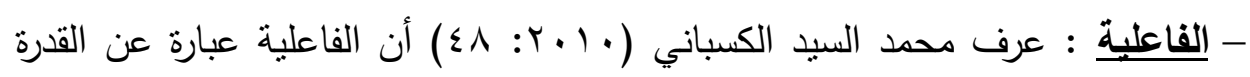
على تحقيق النتيجة المقصودة وفق معايير محددة مسبقًا أو هي القدرة على إنجاز

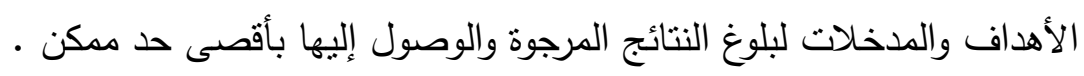

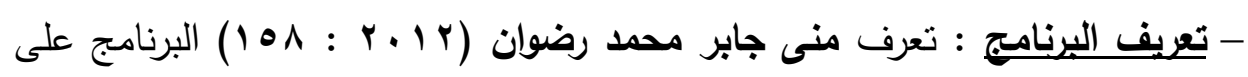
إنه: "مجموعة من الأنشطة والخبرات المتتوعة المخططة والمنظمة والتي تسنتد إلى دئى أسس وفنبات نظريات تعديل السلوك وتتضمن مجموعة من المهارات والممارسات

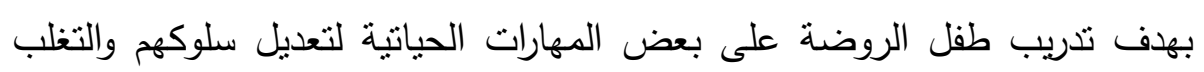
على بعض المشكلات الحياتية". 


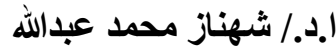

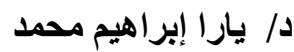

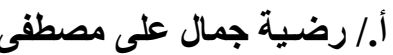

فاعلية أنشطة البراعم في تحقيق نواتج

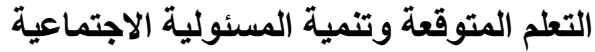

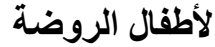

التعريف الإجرائي للبرنامج بأنه:

يعرف البرنامج طبقًا للبحث الحالي بأنه: مخطط منظم لتقديم مجموعة من الأنشطة والممارسات العملية التي يقوم بها الأطفال تحقق نواتج التعلم المتوقعة وتتمي المسئولية الإجتماعية لطفل الروضة.

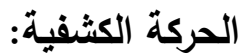

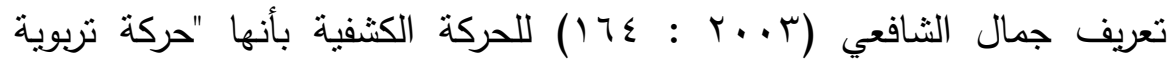

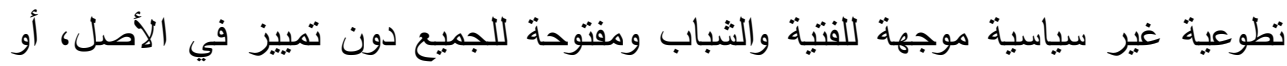
الجنس، أو العقيدة وفقًا للهدف والمبادئ والطريقة التي عبر عنها مؤسس الحركة".

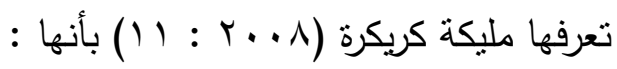

"حركة تربوية، تهدف لمساعدة الفتية والثباب على تتمية معارفهم واتجاهاتهم التي تؤهلهم في المستقبل لتحمل المسئولية، الثقة بالنفس، المواطنة، ليكونوا قادة الغد " . مرحلة البراعم: مرحلة البراعم من (ع-7 )سنوات " هي مرحلة لبناء الطفل حركيًا وبدنيًا وسلوكيًا من خلال أنشطة تربوية تتميز باللعب والحركة حتى يتمكن من تكوين منين الثخصية المتكاملة و تتكل حجر الأساس لمراحل الكثافة المتلاحقة " لئل التعريف الإجرائي لأنشطة البراعم :

"مخطط منظم لتقديم مجموعة من الأنشطة والخبرات الكثفية والممارسات العملية التي يقوم بها الأطفال والتي تتضمن أنشطة حركية - موسيقية - فنية - بيئية - إجتماعية ومعسكرات، تهدف إلى تتمية المسئولية الإجتماعية وتحقق نواتج التعلم لدى طفل الروضة، تتفذ بطريقة معينة في مدة زمنية محددة ولها أسلوب للتقويم ".

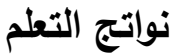

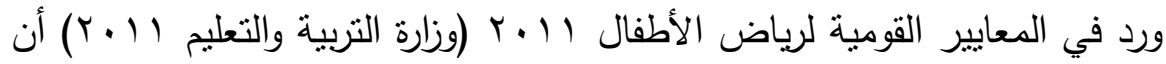
المواصفات والخصائص التى نتوقع أن يكتمل نكونها لدى الطفل مع انتهائه من مرحلة

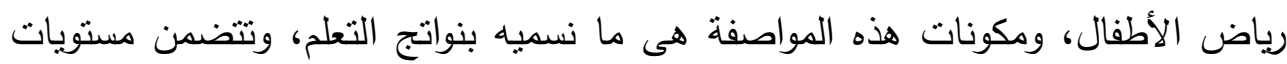


معيارية لكل ما يجب أن يحمله المتعلم ويكتسبه عبر مرحلة رياض الأطفال من معارف ومهارات شخصية وإجتماعية وكذا العادات والقيم والمفاهيم المختلفة، التي تمكنه من التتشئة السليمة وإعداد شخصيته وتتمية قدراته بما يمكنه من التطور التربوي عبر المراحل التعليمية التالية.

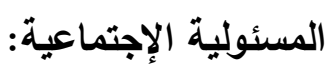

عرفتها حسنية غنيمي(· ( + ب) بأنها: "مفهوم يعبر عن محصلة استجابات الطفل لقيامه بدور محدد نحو نفسه، ونحو أسرته، ونحو مجتمعه، معرفته لحقوقه وواجباته من بن بانهات خلال المواقف التي يتعرض لها". ويعرفها يوسف عبد الله (ع ا +r)، المسئولية الاجتماعية على أنها : "الواجبات التي يؤديها الفرد تجاه الجماعة وتصب في صالحها وتظهر في سلوكيات إجتماعية إيجابية يقوم بها تجاه الآخرين " . التعريف الإجرائي للمسئولية الإجتماعية : "التزام الطفل بتأدية واجباته تجاه مجتمعه، هذا الالتزام نابع من التزامه تجاه أسرته وتجاه ذاته ومعرفته بحقوقه وواجباته" .

\section{منهج الاراسة:}

استخدمت الدراسة الحالية المنهج شبه التجريبي ذو المجموعة الواحدة حيث يتم

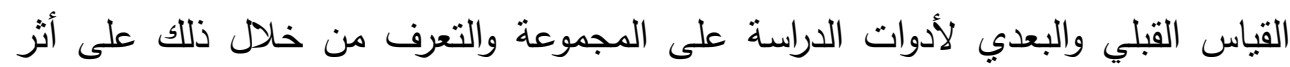
المتغير التجريبي (البرنامج المقترح) على المتغيرين التابعين (نواتج التعلم، المسئولية الإجتماعية لطفل الروضة). 
أ- توجد فروق دالة إحصائًا بين متوسطات درجات أطفال المجموعة التجريبية-

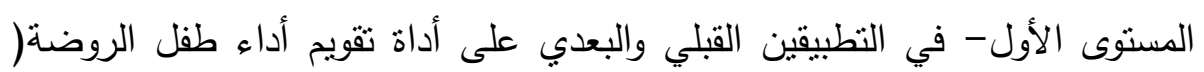
المقياس المتدرج لنواتج التعلم ) لصالح التطبيق البعدي.

ب- توجد فروق دالة إحصائيًا بين متوسطات درجات أطفال المجموعة التجريبية-

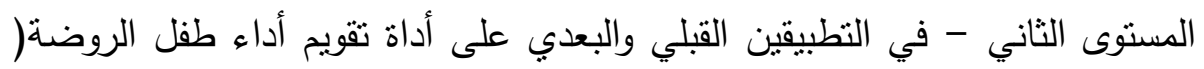
المقياس المتدرج لنواتج التعلم ) لصالح التطبيق البعدي. الفرض الثاني : - | (الثي

أ- توجد فروق دالة إحصائًًا بين متوسطات درجات أطفال المجموعة التجريبية المستوى الأول- في النطبيقين القبلي والبعدي على مقياس المسئولية الإجتماعية لطفل الروضة لصالح التطبيق البعدي.

ب- نوجد فروق دالة إحصائًًا بين متوسطات درجات أطفال المجموعة التجريبية المستوى الثاني - في التطبيقين القبلي والبعدي على مقياس المسئولية الإجتماعية لطفل الروضة لصالح النطبيق البعدي. خطوات وإجراءات الدراسة: الطريقة والإجراءات: أولاً: الأدوات المستخدمة في الدراسة : استخدمت الدراسة الحالية الأدوات التالية للتحقق من فروض الدراسة:

(إعداد الباحثة) 1- مقياس المسئولية الإجتماعية المصور لطفل الروضة.

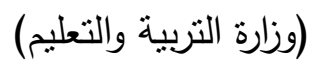
r - المقياس المتدرج لنواتج تعلم طفل الروضة . 
(إعداد الباحثة) r- - برنامج أنشطة البراعم

أولاً : مقياس المسئولية الاجتماعية المصور لطفل الروصة : - تحديد الهدف من المقياس . هدف مقياس المسئولية الاجتماعية المصور لطفل الروضة إلى قياس نمو المسئولية الاجتماعية لدى الطفل محور الدراسة. - إعداد الصورة الأولية للمقياس. - يتكون مقياس المسئولية الاجتماعية المصور لطفل الروضة في صورته النهائية من

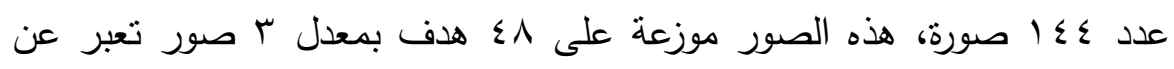

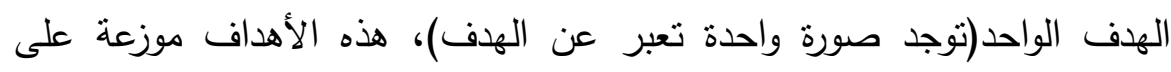

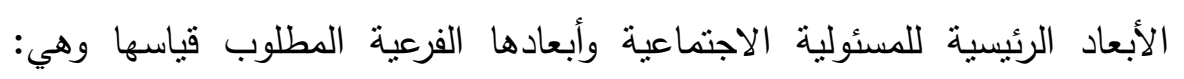
الإعتماد على النفس (النظافة- الطعام -الملابس- النظام- السلامة والأمن). - أداب السلوك (السلام - الاستئذان - سلوك الكلام - سلوك الزيارة) . - المشاركة (في المنزل - في الروضة - في الثارع)، يختار الطفل صورة واحدة تعبر عن مدلول العبارة الواردة تحت الهدف.

- طريقة تصحيح المقياس:

يعطى الطفل درجة واحدة في حالة اختيار البديل الصحيح، وصفر في حالة اختيار

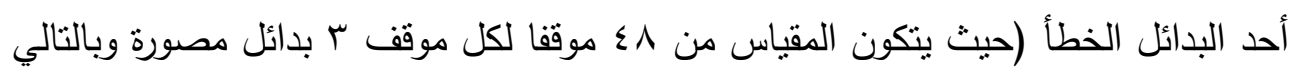

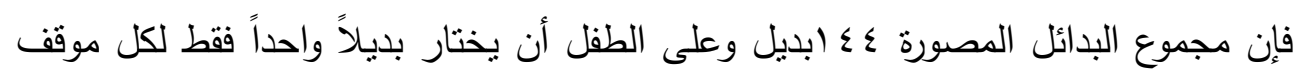
يسجله الفاحص في استمارة استجابات الطفل) وبذلك تكون أعلى درجة يحصل عليها الطفل

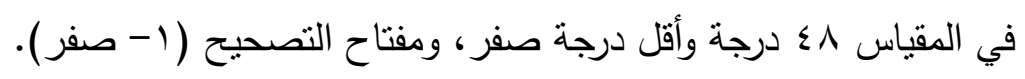




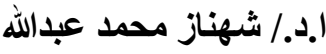

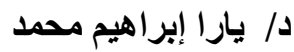

فاعلية أنثطة البراعم في تحقيق نواتج التجائ التعلم المتوقعة وتنمية المسئولية الاجتماعية نوانية

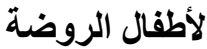

التجرية الإستطلاعية لمقياس المسئولية الاجتماعية المصور للطقل :

تم تطبيق المقياس على عينة استطلاعية عددها (·r) طفل وطفلة تتراوح أعمارهم بين (ع-7) سنوات بروضة مدرسة كوم أبو شيل الإبتدائية في الفصل الدراسي

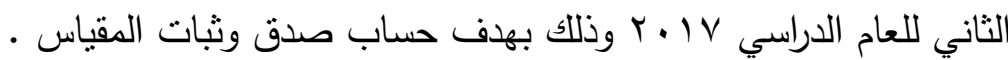
حساب معامل صدق مقياس المسئولية الاجتماعية المصورلطقل الروضة . الصدق Validity

$$
\text { اعتمدت الباحثة في حساب صدق المقياس على ما يلي: }
$$

\section{Logical Validity أ- الصدق المنطقي ( صدق المحكمين )}

تم عرض المقياس على مجموعة من السادة المحكمين المتخصصين في مجال رياض الأطفال، والمناهج وطرق التدريس، والذين كانت لهم دراسات أو أبحاث في هذاء هن

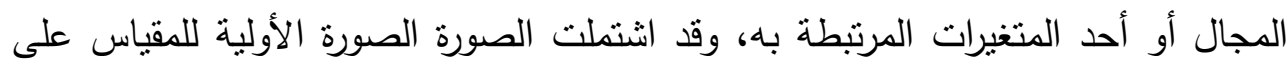

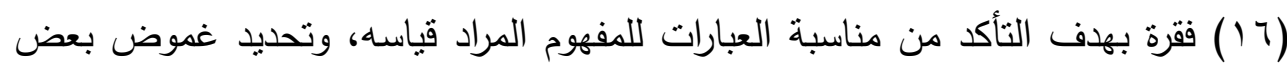

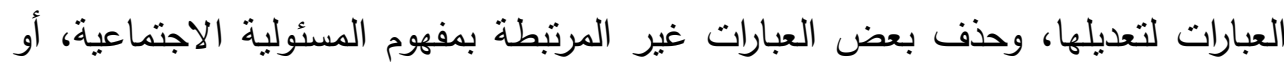
غير مناسبه لطبيعة وخصائص الأطفال.

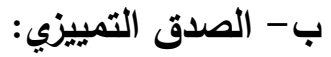

تم حساب الصدق التمييزي لمقياس المسئولية الاجتماعية المصور لطفل الروضة عن طريق حساب دلالة الفروق بين الإرباعي الأعلى والإرباعي الأدنى لدرجات الاطفال

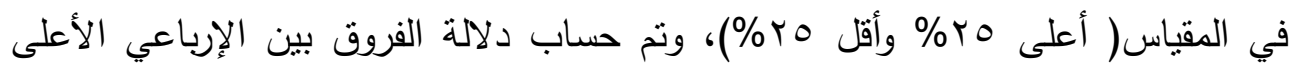
والأدنى عن طريق حساب اختبار "Z" مان ويتتي لالالة الفروق بين متوسطي درجات الأطفال في المجموعنين العليا والدنبا. وقد جاءت قيمة Z دالة عند مستوى دلالة ا ...مما يؤكد ارتفاع الصدق التمييزي لمقياس المسئولية الاجتماعية المصور لطفل الروضة. 
:Reliability الثبات

حساب ثبات مقياس المسئولية الاجتماعية المصور لطفل الروضة من خلال :

: Alpha Cronbach Method طريقة ألفا كرونباك -

تم إستخدام معادلة ألفا كرونباك وهي معادلة تستخدم لإيضاح المنطق العام الثبات

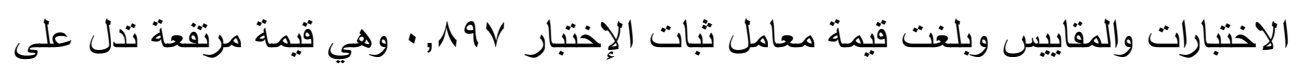
ثبات الإختبار

- طريقة إعادة تطبيق الاختبار Test- Retest -

تم إستخدام طريقة إعادة الاختبار لحساب ثبات المقياس بعد تطبيقه على العينة

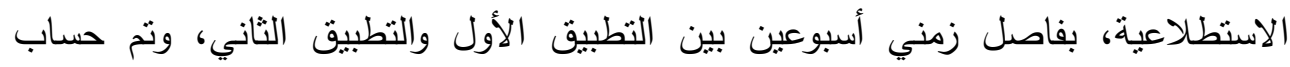

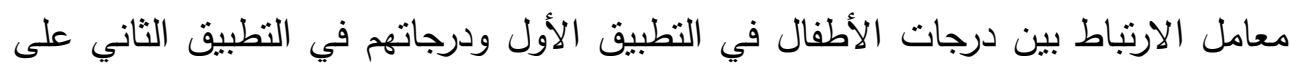

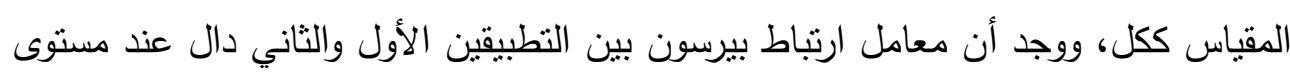
دلالة ا ... . مما يدل على ثبات المقياس .

ثانياً - المقياس المتدرج لنواتج التعلم المعد من قبل وزارة التربية والتعليم . تم تحديد عدد من مؤشرات نواتج التعلم التي يمكن تحقيقها لدى طفل الروضة بعد

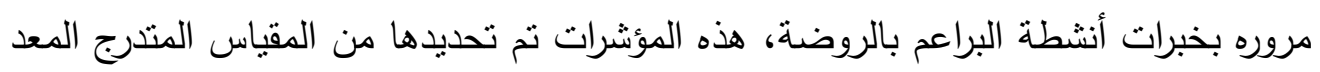

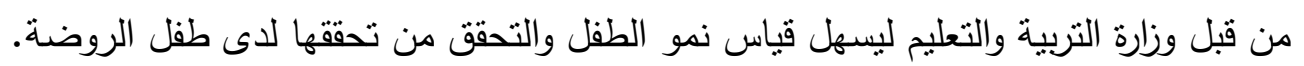
الهدف من المقياس: - معرقة مدى تحقق بعض نواتج التعلم لطفل الروضة . - مكونات المقياس: يتكون المقياس المتدرج لنواتج التعلم من خمس مجالات هي مجالات

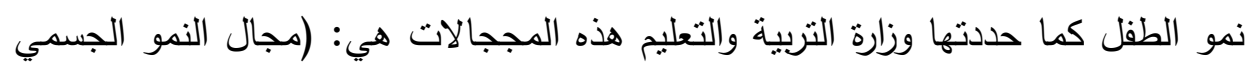

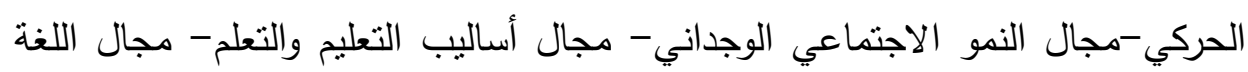
والتواصل-مجال الوعي والمعرفة العامة).

يندرج تحت هذه المجالات عدد من المعايير ومنها مؤشرات نواتج التعلم تم تحديد

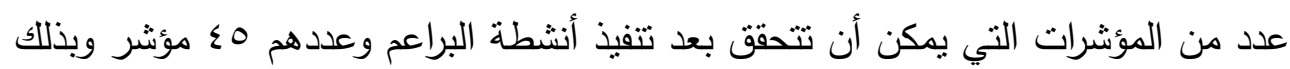




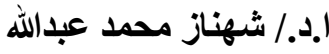

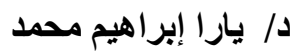

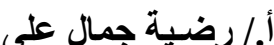

فاعلية أنثطة البراعم في تحقيق نواتج

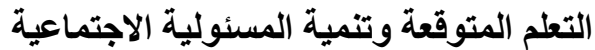

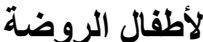

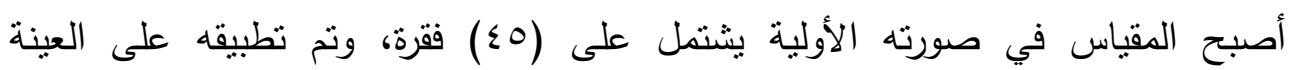
الاستطلاعبة للاستقرار على الصورة النهائية له. طريقة تصحيح المقياس:

تمثل عدد عبارات المقياس في صورته الأولية (0؛) فقرة لها ثلاثة بدائل في

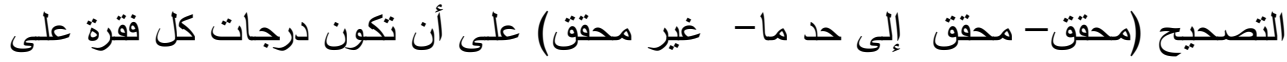

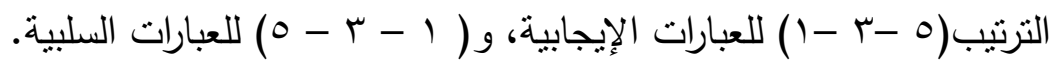

- التجربة الاستطلاعية للمقياس المتدرج لنواتج التعلم . تم تطبيق المقياس على عينة استطلاعية عددها (·r) طفل وطفلة نتراوح أعمارهم بين(ع-7) سنوات بروضة مدرسة كوم أبو شيل الإبتدائية في الفصل الدراسي الثاني للعام الدراسي V V ا r وذللك بهدف حساب صدق وثبات المقياس . حساب صدق المقياس المتدرج لنواتج التعلم: (1) الصدق Validity : نت حساب صدق المقياس كما يلي: Logical Validity أ- الصدق المنطقي ( صدق المحكمين )

تم عرض الصورة الأولية للمقياس على مجموعة من السادة المحكمين المتخصصين

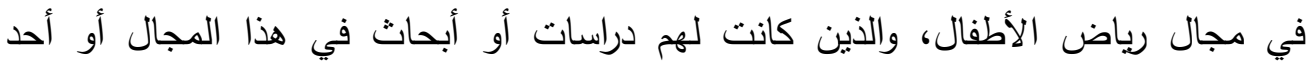
المتغيرات المرتبطة به، وقد اشتملت نلك الصورة على (0؛) فقرة بهدف: التأكد من مناسبة العبارات للمفهوم المراد قياسه، وتحديد غموض بعض العبارات لتعديلها، وحذف بعض في لهن

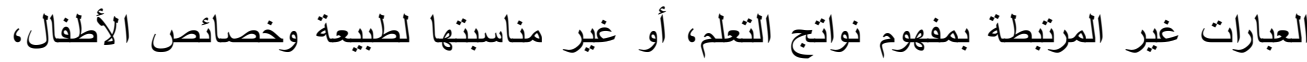
وتم تطبيقه على العينة الاسنطلاعية للاستقرار على الصورة النهائية له.

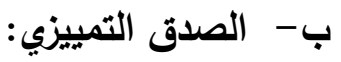

تم حساب الصدق التمبيزي للمقياس المندرج لنواتج التعلم لطفل الروضة عن طريق

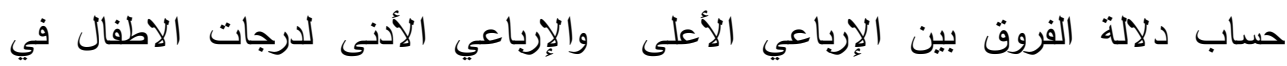

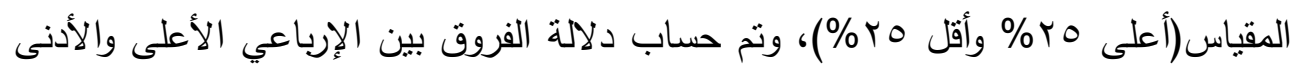


عن طريق حساب اختبار "Z" مان ويتتي لدلالة الفروق بين متوسطي درجات الأطفال في

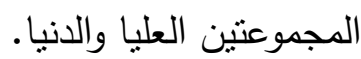

وقد وجد أن قيمة دالة عند مستوى دلالة ا ...مما يؤكد ارتفاع الصدق التمييزي ل كقياس نواتج التعلم لطفل الروضة. :Reliability الثبات

: Alpha Cronbach Method طريقة ألفا كرونباك تم إستخدام معادلة ألفا كرونباك وهي معادلة تستخدم لإيضاح المنطق العام لثبات

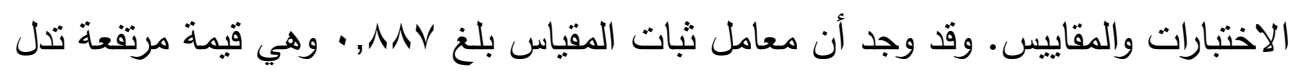

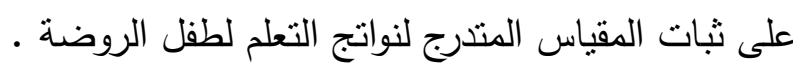
- Test- Retest طريقة إعادة تطبيق الاختبار تم استخدام طريقة إعادة الاختبار لحساب ثنات المقياس المنترج لنواتج التعلم بعد التبد

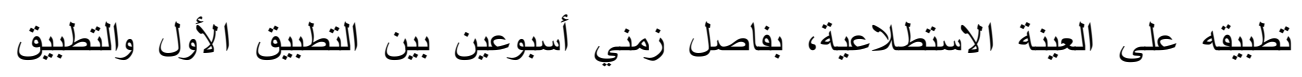

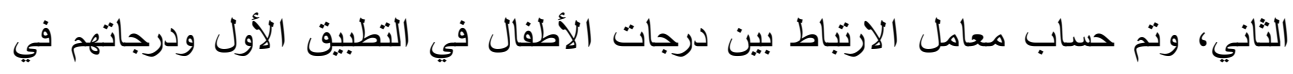

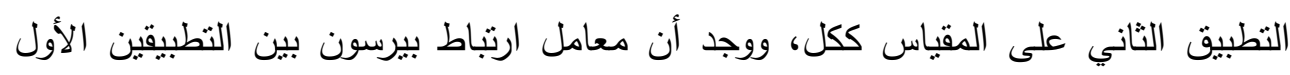

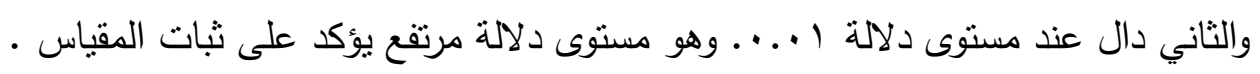
خامساً : إعداد برنامج أنثطة البراعم : تم إعداد البرنامج المقترح القائم على انثطة البراعم في ضوء خطوات إعداد برامج أطفال الروضة وخصائصهم النمائية .

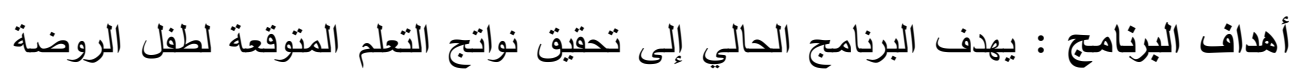

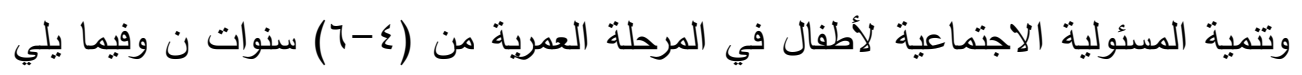
تحديد الأهداف الإجرائية بالبرنامج: 
ا.د./ شهناز محمد عبدالله

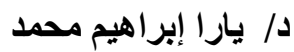

أ./ رضية جمال على مصطفى
فاعلية أنشطة البراعم في تحقيق نواتج

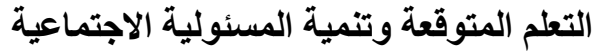

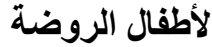

بعد الإنتهاء من تتفيذ أنشطة البرنامج يتوقع من الطقل أن يكون قادراً على أن:

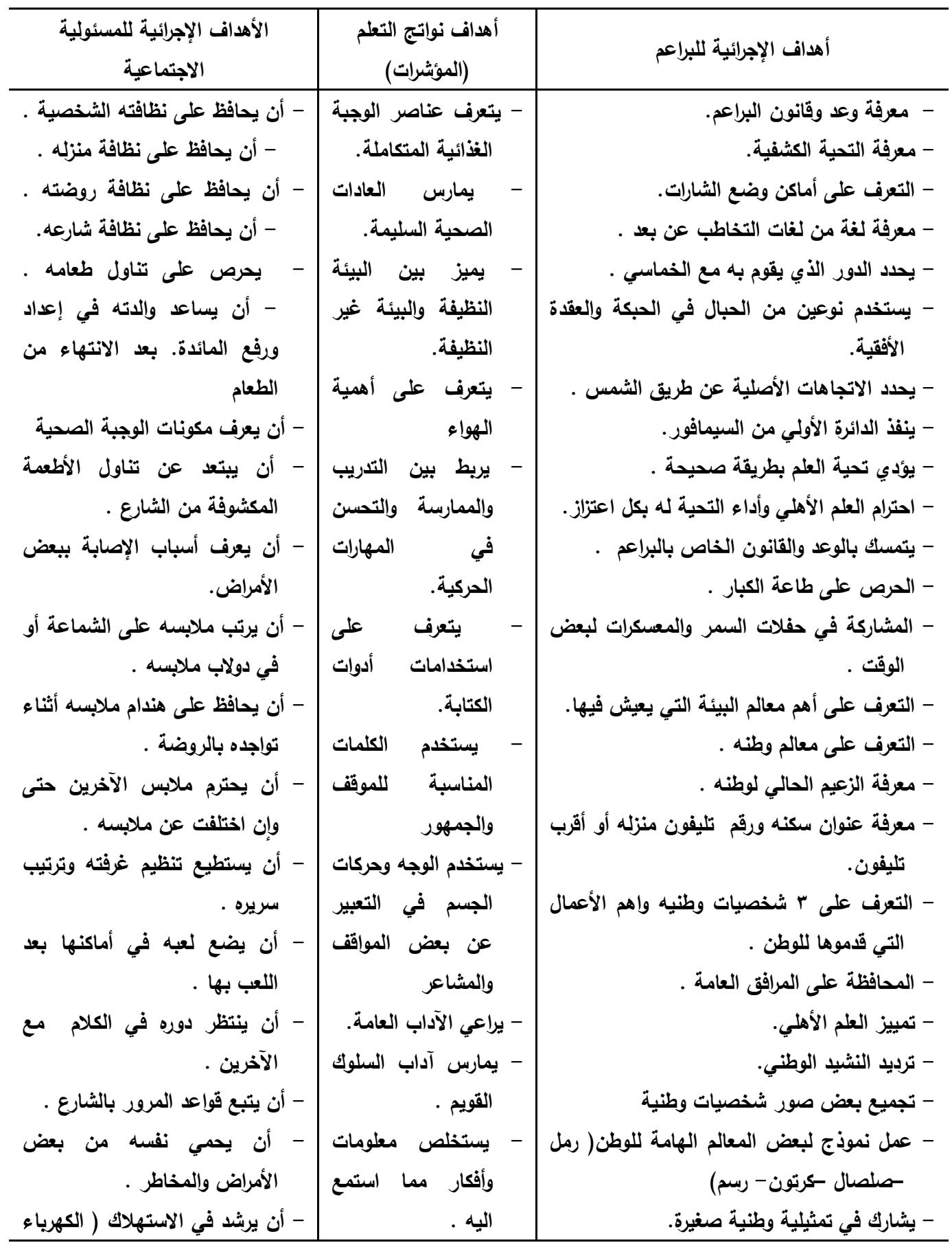


المجلة العلمية لكلية رياض الاطفال - جامعة اسيوط

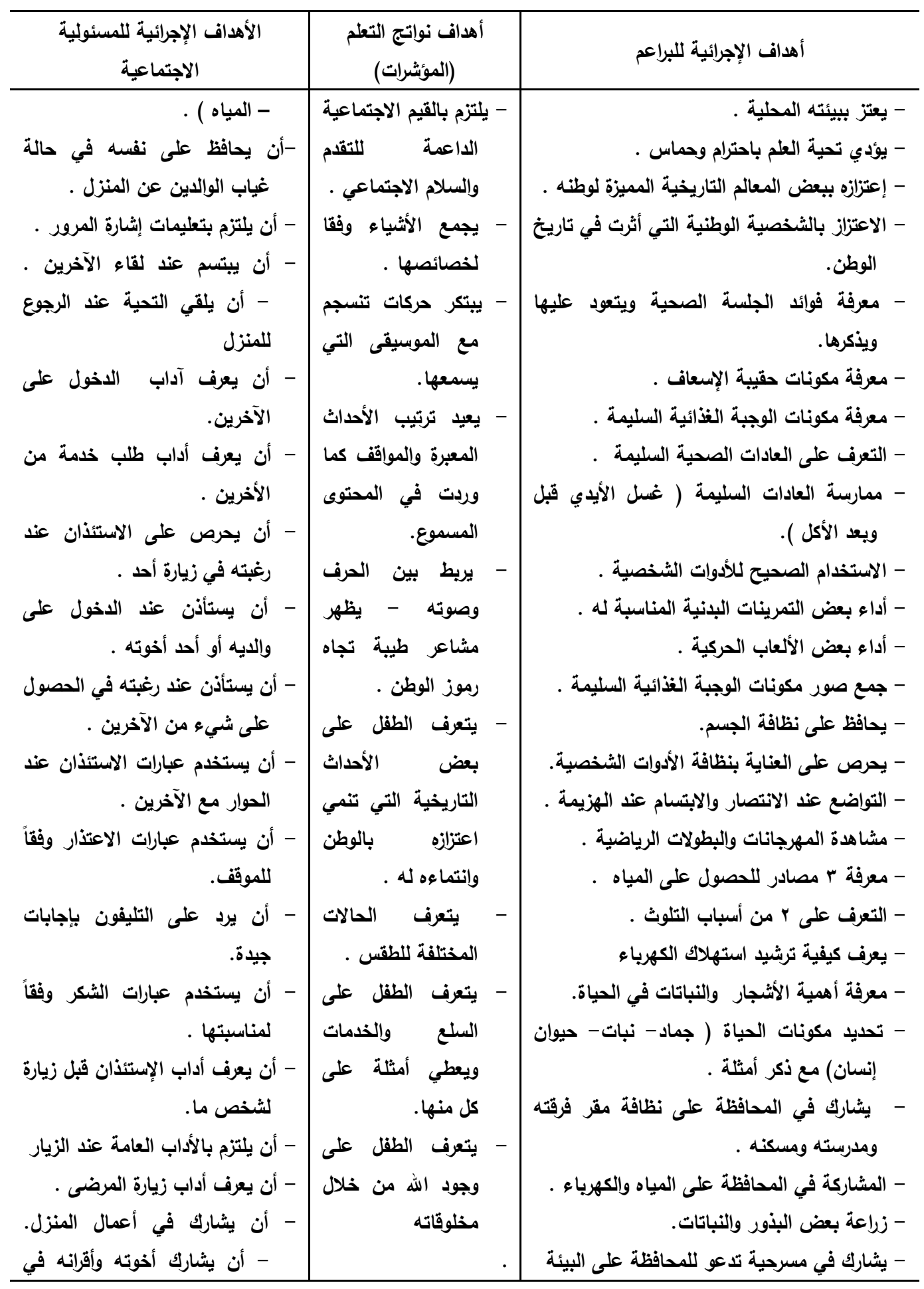


ا.د./ شهناز محمد عبدالله

فاعلية أنشطة البراعم في تحقيق نواتج

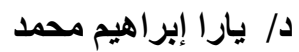

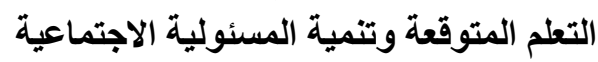

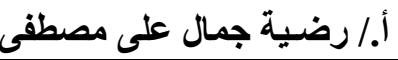

لأطفال الروضة ونماكه

\begin{tabular}{|c|c|c|}
\hline الأهداف الإجرائية للمسئولية & 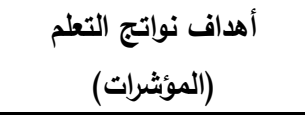 & أهداف الإجرائية للبراعم \\
\hline 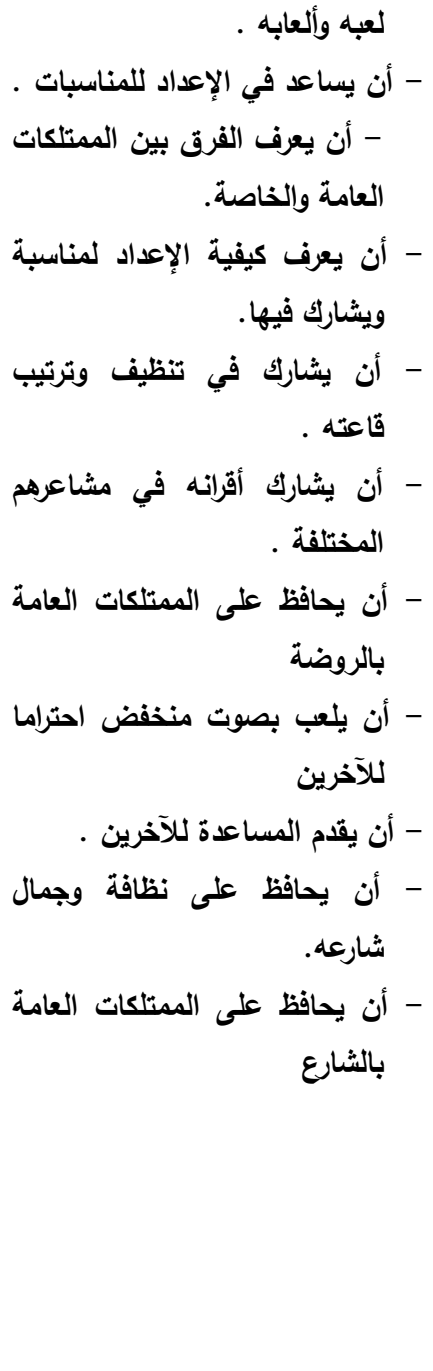 & 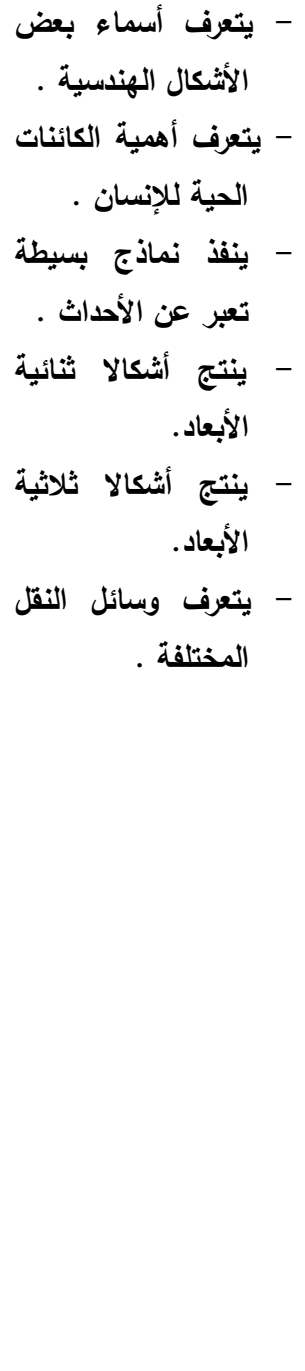 & 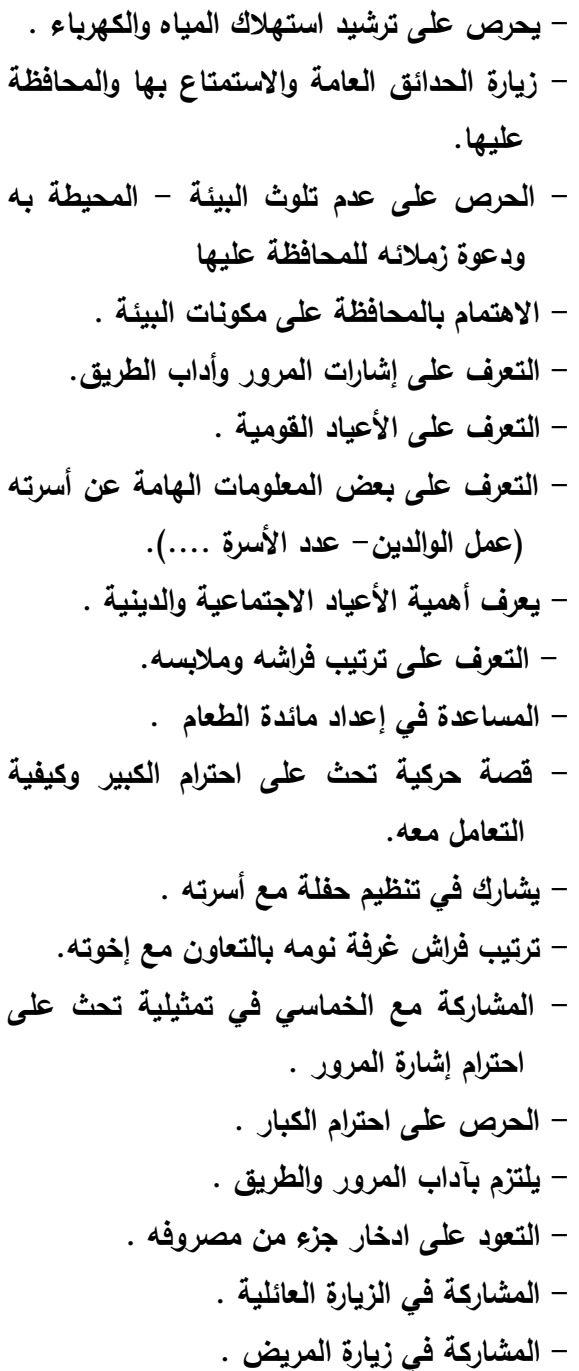 \\
\hline
\end{tabular}

لمن يقدم هذا البرنامج :

يستهدف البرنامج المقدم المرحلة العمرية من (ع-7) سنوات، والأنشطة التي

تتناسب مع المستوى الأول والثاني لطفل الروضة. 


\section{الأنشطة المتضمنة داخل لقاءات البرنامج :}

تضمن البرنامج المقترح مجموعة من الأنشطة التي بني عليها و تحقيق نواتج

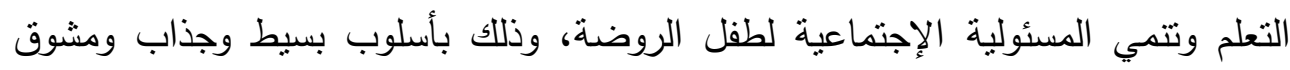

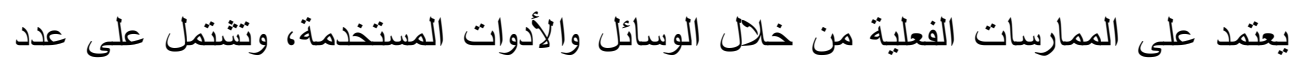

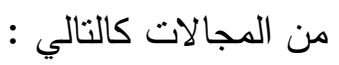

\begin{tabular}{|c|c|}
\hline أمثـــــة & النشاط \\
\hline 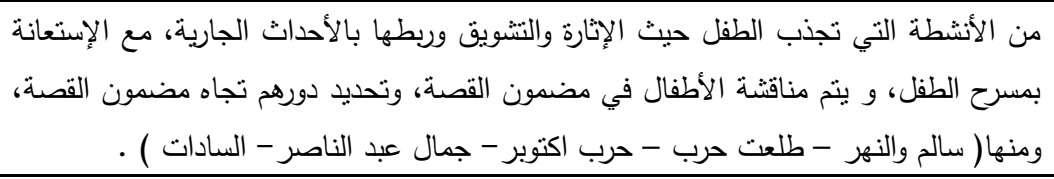 & الأنشطة القصصية \\
\hline 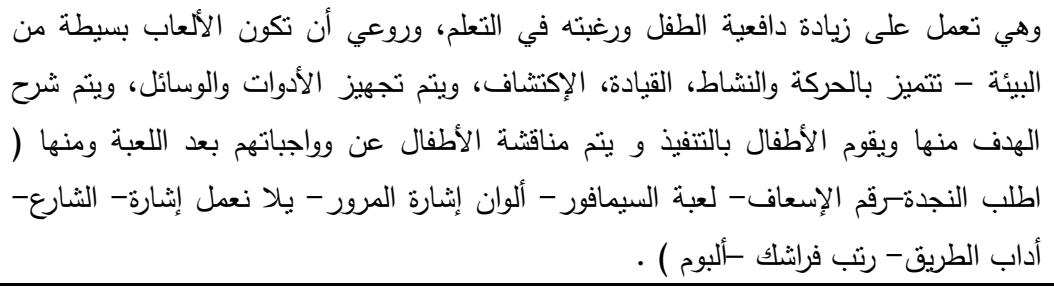 & الألعاب التعليمية \\
\hline 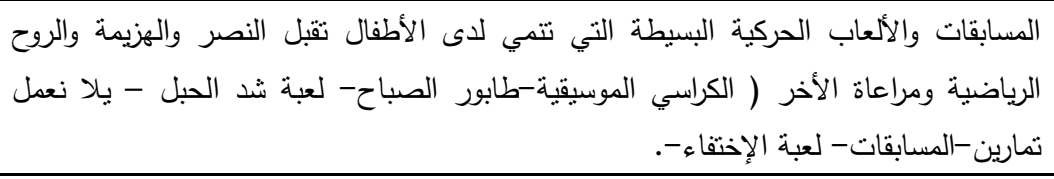 & الأنشطة الحركية \\
\hline 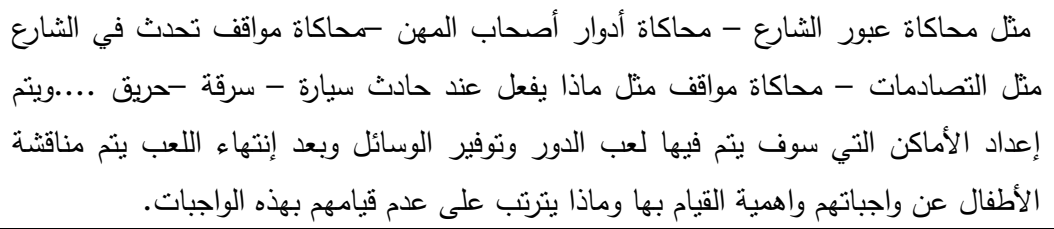 & لعب الادوار \\
\hline 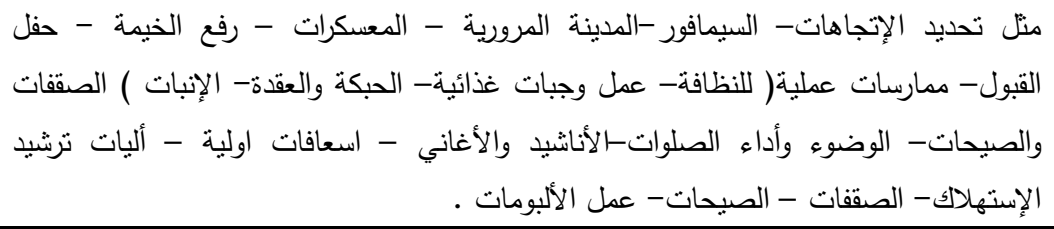 & ممارسة عملية \\
\hline الإستعراضات - أغاني المناسبات الوطنية والقومية - أغاني الإحتفال بأعياد الميلاد - & الأنثطة الموسيقية \\
\hline 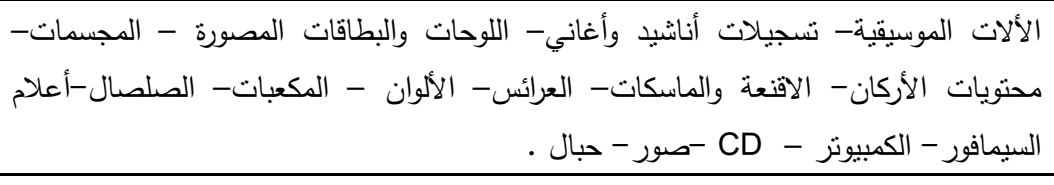 & والبصرية والحسية السمعية \\
\hline الرسم الحر والمقيد - التلوين الحر والمقيد . & الأنشطة الفنية \\
\hline
\end{tabular}


ا.د./ شهناز محمد عبدالله

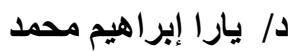

أ./ رضية جمال على مصطفى ملمثل
فاعلية أنشطة البراعم في تحقيق نواتج التعلم المتوقعة وتنمية المسئولية الاجتماعية فئية

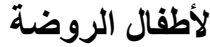

الخطة الزمنية لتفيذ البرنامج :

\begin{tabular}{|c|c|c|c|c|c|c|c|c|}
\hline ساعات & للأنشطة الكلي & زلنشاط & أنشطة & المعسكرات & الأنشطة & زمن اللقاء & اللقاءات & زمن التففيذ \\
\hline . عـ اعاعة & نشاط & من • r إلى 0؛ ق & 9 نشاط & 9معسكرات & r ب نشاط & r ساعة & r & بـ يوم \\
\hline
\end{tabular}

تقويم البرنامج : تم ثقويم البرنامج على ثلاث مراحل :

- التقييم القبلي أو المبدئي:

ويتم هذا النوع من التقييم قبل تطبيق البرنامج وذلك بتطبيق المقاييس المستخدمة

في الدراسة وهي: (المقياس المتدرج لنواتج التعلم- مقياس المسئولية الاجتماعية المصور لطفل الروضة) وهذه المقاييس يتم تطبيقها على المجموعتين (التجريبية والضابطة) ويتم تسجيل درجات أطفال العينة بإستمارة تسجيل خاصة بكل مقياس. - التقويم التكويني أو البنائي :

وبتم هذا النوع من التقييم من خلال الأسئلة والأنشطة التقوبمية التي يتعرض لها الأطفال بنهاية كل نشاط وبنهاية كل معسكر اليوم الواحد المعدة داخل البرنامج.

- التقييم البعدي أو النهائي :

ويتم هذا النوع من التقييم بنهاية البرنامج حيث يتم إعادة تطبيق جميع المقاييس السابق ذكرها على عينة الدراسة وذلك بعد الانتهاء من تطبيق برنامج البراعم لأطفال

$$
\begin{aligned}
& \text { الروضة من (ع-7) سنوات. } \\
& \text { تحيكم البرنامج : }
\end{aligned}
$$

تم عرض برنامج البراعم على عدد من المحكمين منهم الخبراء الأكاديميين في المناهج وطرق التدربس وتربية الطفل والتربية الكثفية بكليات التربية جامعة أسيوط - كلية 
التربية الرياضية جامعة أسيوط - كلية التربية الرياضية جامعة الوادي الجديد - كلية التربية

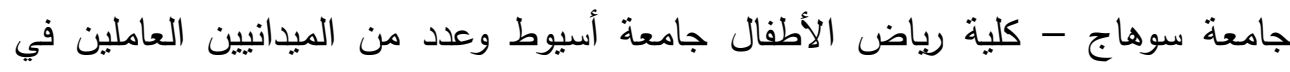
الكثافة والبراعم والمتخصصين في الكثافة و رياض الأطفال، معلمات رياض أطفال قمن الطن بتنفيذ البراعم مع أطفال الروضة، وذللك للتأكد من صلاحية الب قبل نامج قبل تطبيقه على فيلى الاطي

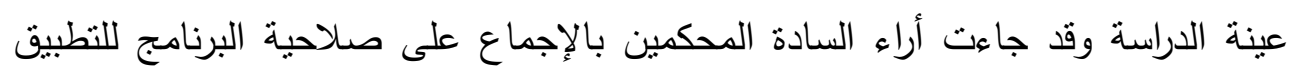
على عينة الدراسة بعد إجراء بعض التعديلات على صياغة بعض الأهداف الإجرائية. ثانياً: الإجراءات التجريبية للاراسة الحالية:

عينة الدراسة: بلغت عينة الدراسة(.7 (17) طفل وطفلة ممن تتراوح أعمارهم من (ع-7) سنوات وملحقين بروضة مدرسة كوم أبو شيل الابتدائية مركز أبنوب - محافظة اسيوط وهي تضم المستويين الأول والثاني لرياض الأطفال. التصميم التجريبي للارا سة: استخدمت الدراسة الحالية المنهج شبه التجريبي ذو

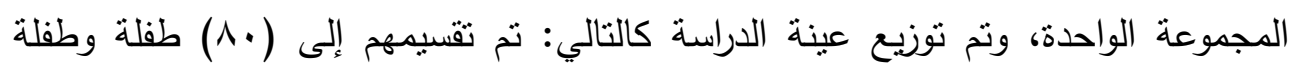
كمجموعة ضابطة، ( • () طفلة وطفلة كمجموعة تجريبية. متغيرات الدراسة : إثتملت الدراسة الحالية على المتغيرات الأتية : أ- المتغير التجريبي (المستقل): وهو أنشطة البراعم وإستخدامها لتحقيق نواتج التعلم المتوقعة لطفل الروضة وتتمية المسئولية الاجتماعية، وتم إستخدام أنشطة البراعم بتفعيل أنشطتها المختلفة للمجموعة التجريبية فقط . لموند ب- المتغيرات التابعة: بعض مؤشرات مجالات نواتج التعلم المعدة من قبل وزارة

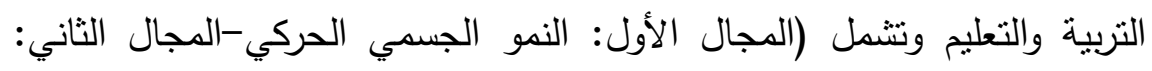

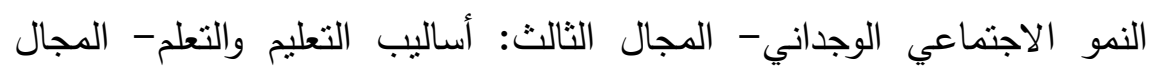
الرابع: اللغة والتواصل-المجال الخامس: الوعي والمعرفة العامة) - - متغيرات تابعة في المسئولية الاجتماعية وهي كالتالي: 


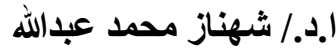

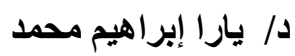

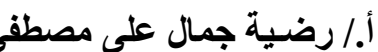

فاعلية أنثطة البراعم في تحقيق نواتج التعلم المتوقعة وتنمية المسئولية الاجتماعية فئية

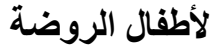

•الاعتماد على النفس متمثل في [النظافة - الطعام - الملابس - النظام -

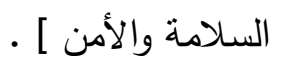

•أداب السلوك وتتشل [السلام - الاستئذان - سلوك الكلام - سلوك الزيارة] .

$$
\text { • المشاركة. [ في المنزل - في الروضة - في الثارع ] • }
$$

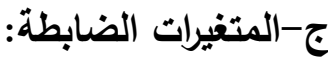

- - العمر الزمني: الأطفال بالمستوى الأول والثاني بالروضة وأعمارهم متقاربة في

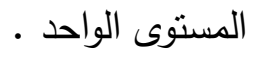

- المستوى الإقتصادي والإجتماعي : نم اختيار عينة الدراسة من روضة واحدة هي روضة مدرسة كوم أبو شيل الإبتدائية بإدارة ابنوب التعليمية وهي روضية الإنة حكومية عامة لا يشترط لقبول الأطفال بها أي مستوى اجتماعي أو اقتصادي. باديه - الظروف الطبيعية أو الفيزيقية: روعي أن يتم العمل بالبرنامج في الفترة

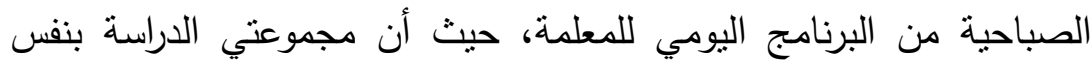
المكان وتتعرض لنفس الظروف الفيزيقية من حرارة وضوء وتهوية ورطوبة. نتائج الاراسة وتحليلها وتفسيرها: أولاً : نتائج الفرض الأول والذي ينص على : أ - توجد فروق دالة إحصائيًا بين منوسطات درجات أطفال المجموعة التجريبيةالمستوى الأول- في التطبيقين القبلي والبعدي للمقياس المتدرج لنواتج التعلم (أداة تقويم أداء طفل الروضة) لصالح التطبيق البعدي. وللتأكد من صحة هذا الفرض تم استخدام إختبارات ت للعينات البارامترية للأزواج المرتبطة من خلال البرنامج الاحصائي Spss وجدول ( ) يوضح ذللك. 
المجلة العلمية لكلية رياض الاطفال - جامعة اسيوط

جدول(1): المتوسط الحسابي والانحراف المعياري وقيمة ت ومستوى الدلالة للفروق بين

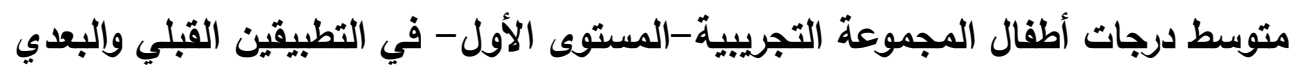
للمقياس المتدرج لنواتج التعلم

\begin{tabular}{|c|c|c|c|c|c|c|}
\hline مستوى الدلالة & Tقيمة & الانحراف & الحستوسطي & العدد & التطبيق & الأبعـاد \\
\hline \multirow{2}{*}{ دال عند ا ... } & \multirow{2}{*}{$r V . . T$} & r.70091 & $9.10 \ldots$ & $\varepsilon$. & قبلي & \multirow{2}{*}{ النمو الجسم والحركي } \\
\hline & & 1.94104 & rr.vo.. & $\varepsilon$. & بعدي & \\
\hline \multirow{2}{*}{ دال عند ا ... } & \multirow{2}{*}{ Ir.r. } & $r . r q \ldots r$ & v..vo. & $\varepsilon$. & قبلي & \multirow{2}{*}{ النمو الاجتماعي الوجداني } \\
\hline & & $1 . . v 1 \leqslant 1$ & Ir..VO. & $\varepsilon$. & بعدي & \\
\hline \multirow{2}{*}{ دال عند ا ... } & \multirow{2}{*}{$r \leq . \leq}$. & 1.99190 & $\leq .10 \ldots$ & $\varepsilon$. & قبلي & \multirow{2}{*}{ أساليب التعليم والتعلم } \\
\hline & & $1 . V \vee \leqslant Y A$ & $1 \leq . . \times 0$. & $\varepsilon$. & بعدي & \\
\hline \multirow{2}{*}{ دال عند ا ... } & \multirow{2}{*}{ r.t. } & Y.117. & 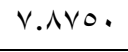 & $\varepsilon$. & قبلي & \multirow{2}{*}{ اللغة والتواصل } \\
\hline & & Y. TV9 & $19.0 \ldots$ & $\varepsilon$. & بعدي & \\
\hline \multirow{2}{*}{ دال عند ا ... } & \multirow{2}{*}{$\varepsilon \ldots r$} & $1 . \varepsilon r T \cdot r$ & $1 \ldots$... & $\varepsilon$. & قبلي & \multirow{2}{*}{ الوعي والمعرفة العامة } \\
\hline & & r.riroq & r..10.. & $\varepsilon$. & بعدي & \\
\hline \multirow{2}{*}{ دال عند ا ... } & \multirow{2}{*}{ ro.00 } & $0.1 \leq r \wedge r$ & rq.vo.. & $\varepsilon$. & قبلي & \multirow{2}{*}{ مقياس نواتج التعلم } \\
\hline & & $1.9 \times 11 \leq$ & $90.7 \times 0$. & $\varepsilon$. & بعدي & \\
\hline
\end{tabular}

\section{يتضح من جدول (1) أنه :}

توجد فروق دالة إحصائًًا بين منوسطات درجات أطفال المجموعة التجريبية المستوى الأول- في التطبيقين القبلي والبعدي لأبعاد ومجموع المقياس المتدرج لنواتج التعلم عند مستوى دلالة ا .... لصالح منوسط درجات الأطفال في النطبيق البعدي. وهذا يؤكد:

أ- فاعلية برنامج أنشطة البراعم لتحقيق نواتج التعلم حيث جاءت النتيجة لصالح أطفال

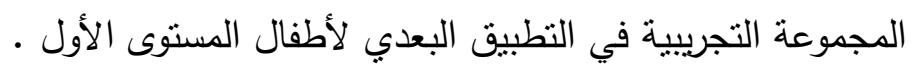




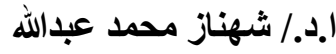

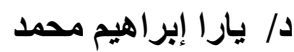

فاعلية أنشطة البراعم في تحقيق نواتج التعلم المتوقعة وتنمية المسئولية الاجتماعية فئية

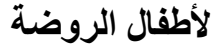

ب- توجد فروق دالة إحصائًا بين متوسطات درجات أطفال المجموعة التجريبية-

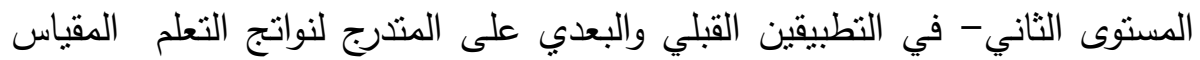
أداة تقويم أداء طفل الروضة (نواتج التعلم) لصالح التطبيق البعدي. للتحقق من صحة هذا الفرض استخدمت الباحثة إختبارات ت للعينات البارامترية للأزواج المرتبطة من خلال البرنامج الاحصائي Spss وجدول (Y) يوضح ذلك. جدول (ץ): المتوسط الحسابي والانحراف المعياري وقيمة ت ومستوى الدلالة للفروق بين متوسط درجات أطفال المجموعة التجريبية- المستوى الثاني - في التطبيقين القبلي والبعدي المقياس المتدرج لنواتج التعلم (نواتج التعلم)

\begin{tabular}{|c|c|c|c|c|c|c|}
\hline مستوى الدلالة & قيمة T T & الانحراف المعياري & الحستوسطي & العدد الع & التطبيق & الأبعـاد \\
\hline \multirow{2}{*}{ دال عند ا ... } & \multirow{2}{*}{$\varepsilon r_{.} . \varepsilon$} & r... $\leqslant$ r & $1 . .7111$ & $\varepsilon \varepsilon$ & قبلي & \multirow{2}{*}{ النموالجسمي } \\
\hline & & $\cdots \cdots$ & $r \ldots .$. & $\varepsilon \varepsilon$ & بعدي & \\
\hline \multirow[b]{2}{*}{ دال عند ا ... } & \multirow[b]{2}{*}{$\varepsilon 9.9 r$} & $1.999 \leqslant v$ & $\varepsilon .90 \leq 0$ & $\varepsilon \varepsilon$ & قبلي & \multirow{2}{*}{ 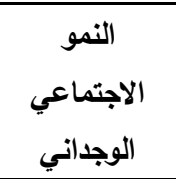 } \\
\hline & & $\cdots \cdots$ & $r \ldots .$. & $\varepsilon \varepsilon$ & بعدي & \\
\hline \multirow{2}{*}{ دال عند ا +.. } & \multirow{2}{*}{$00 . V Y$} & $1.799 \leq$. & 0.474 & $\varepsilon \varepsilon$ & قبلي & \multirow{2}{*}{ أساليب التعليم } \\
\hline & & 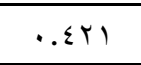 & 19.9 .91 & $\varepsilon \varepsilon$ & بعدي & \\
\hline \multirow{2}{*}{ دال عند •... } & \multirow{2}{*}{$\leqslant 7.0$. } & r.1011r & V.EVVT & $\varepsilon \varepsilon$ & قبلي & \multirow{2}{*}{ اللغة والتواصل } \\
\hline & & $1.19 \times 7$. & $r \leq . V . \leq 0$ & $\varepsilon \varepsilon$ & بعدي & \\
\hline \multirow{2}{*}{ دال عند ا ... } & \multirow{2}{*}{ O^.乏. } & r.r.YI. & 14.1091 & $\varepsilon \varepsilon$ & قبلي & \multirow{2}{*}{ والمعرفة العامة } \\
\hline & & $1 . r+1$ & r^.乏.q1 & $\varepsilon \varepsilon$ & بعدي & \\
\hline \multirow{2}{*}{ دال عند •.. } & \multirow{2}{*}{$\vee \wedge . .9$} & V.MITIE & E..YTVK & $\varepsilon \varepsilon$ & قبلي & \multirow{2}{*}{ مقياس نواتج } \\
\hline & & r.11 & ITY.VV & $\varepsilon \varepsilon$ & بعدي & \\
\hline
\end{tabular}

يتضح من جذول (r) أنه:

توجد فروق دالة إحصائًًا بين متوسطات درجات أطفال المجموعة التجريبية -

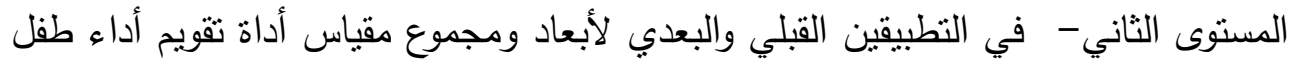


الروضة (المقياس الددرج لنواتج التعلم) عند مستوى دلالة ا....، لصالح منوسط درجات الأطفال في النطبيق البعدي. وهذا يؤكد على :

- إرتفاع درجات المجموعة التجريبية في التطبيق البعدي لأطفال المستوى الثاني بعد تطبيق برنامج أنشطة البراعم.

- فاعلية برنامج أننطة البراعم لتحقيق نواتج التعلم المتوقعة لطفل الروضة . تعقيب عام على الفرض الأول :

بعد استعراض نتائج الفروض الفرعية للفرض الأول والذي تتاول نواتج التعلم

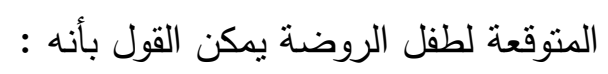

ا - إرتفاع درجات المجموعة التجريبية في التطبيق البعدي للمقياس المدرج لنواتج

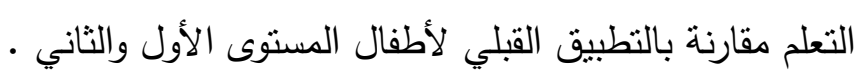
r - تأكيد صحة الفرض الأول حيث يوجد فروق ذات دلالة إحصائية بين متوسطي

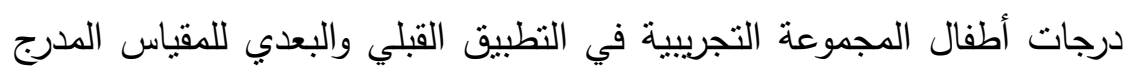

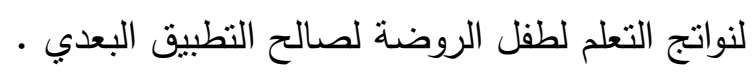
r- فاعلية برنامج انشطة البراعم في تحقيق نواتج التعلم المتوقعة لطفل الروضة وقياسها ماعله برنات القرض الثاني أ - "توجد فروق دالة إحصائيًا بين متوسطات درجات أطفال المجموعة التجريبيةالمستوى الأول- في التطبيقين القبلي والبعدي على مقياس المسئولية الإجتماعية لطفل الروضة لصالح التطبيق البعدي. للتحقق من صحة هذا الفرض استخدمت الباحثة إختباراتات للعينات البارامترية للأزواج المرتبطة من خلال البرنامج الاحصائي Spss وجدول (r) يوضح ذلآلك. 


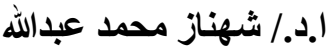

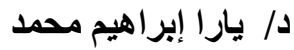

فاعلية أنثطة البراعم في تحقيق نواتج

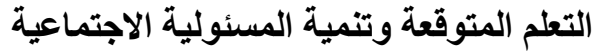

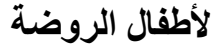

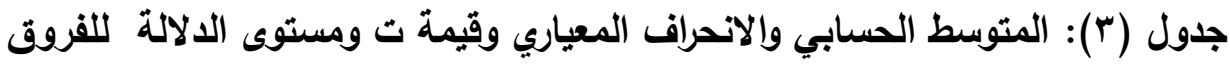
بين متوسط درجات أطفال المجموعة التجريبية المستوى الأول - في التطبيقين القبلي

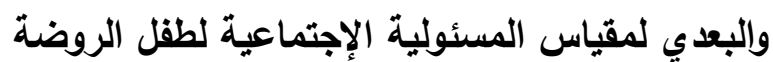

\begin{tabular}{|c|c|c|c|c|c|c|}
\hline مستوى الدلالة & قيمة T & الانعراف & المتوسط & العدد & التطبيق & الأبعاد \\
\hline \multirow{2}{*}{ دال عند ا ... } & \multirow{2}{*}{ tr.IT } & $1 .+r \leqslant 9 V$ & V.ovo. & $\varepsilon$ & قبلي & \multirow{2}{*}{ الإعتماد على النفس } \\
\hline & & r.11990V & IE.TYO. & $\varepsilon$ & بعدي & \\
\hline \multirow{2}{*}{ دال عند ا ... } & \multirow{2}{*}{$r T .00$} & $1 . M 19 \leq 1$ & $7.90 \ldots$ & $\varepsilon$ & ق قبلي & \multirow{2}{*}{ أداب السلوك } \\
\hline & & 1.0 .000 & Ir.T... & $\varepsilon$ & بعدي & \\
\hline \multirow{2}{*}{ دال عند ا ... } & \multirow{2}{*}{$r \cdot . V \leq$} & 1.r997 & $0 . r \ldots$ & $\varepsilon$ & قبلي & \multirow{2}{*}{ المشاركة } \\
\hline & & 1.10409 & $9 . \leqslant 0 \ldots$ & $\varepsilon$ & بعدي & \\
\hline \multirow{2}{*}{ دال عند ا ... } & \multirow{2}{*}{ rV.OV } & 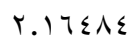 & $19.7 \times 0$. & $\varepsilon$ & قبلي & \multirow{2}{*}{ مقياس المسئولية } \\
\hline & & r.V7091 & ro.svo. & $\varepsilon$. & بعدي & \\
\hline
\end{tabular}

يتضح من جدول (r) أنه:

توجد فروق دالة إحصائيًا بين متوسطات درجات أطفال المجموعة التجريبية المستوى الأول-في التطبيقين القبلي والبعدي لأبعاد ومجموع مقياس المسئولية الإجتماعية لطفل الروضة عند مستوى دلالة ا ...، لصالح متوسط درجات الأطفال في التطبيق البعدي.

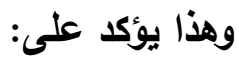

- - إرتفاع درجات أطفال المستوى الأول على مقياس المسئولية الإجتماعية في التطبيق

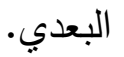

- فاعلية برنامج أنشطة البراعم في تتمية المسئولية الإجتماعية لطفل الروضة

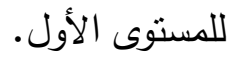

ب- "توجد فروق دالة إحصائيًا بين متوسطات درجات أطفال المجموعة التجريبيةالمستوى الثاني-في التطبيقين القبلي والبعدي على مقياس المسئولية الإجتماعية لطفل الروضة لصالح التطبيق البعدي. 
للتحقق من صحة هذا الفرض استخدمت الباحثة إختبارات ت للعينات البارامترية للأزواج المرنبطة من خلال البرنامج الاحصائي Spss وجدول (ع ) يوضح ذللك. جدول (؛): المتوسط الحسابي والانحراف المعياري وقيمة ت ومستوى الدلالة للفروق بين متوسط درجات أطفال المجموعة التجريبية - المستوى الثاني - في التطبيقين القبلي

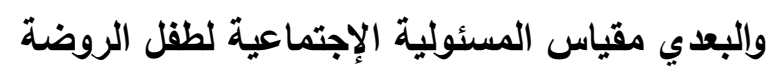

\begin{tabular}{|c|c|c|c|c|c|c|}
\hline مستوى الدلالة & قيمة T & الانحراف & الحسابي & العدد & التطبيق & الأبعاد \\
\hline \multirow{2}{*}{ دال عند ا ... } & \multirow{2}{*}{$r \wedge .91$} & $1.7 V \ldots 7$ & 7.7V0. & $\varepsilon$. & قبلي & \multirow{2}{*}{ الإعتماد على النفس } \\
\hline & & r.7.170 & $17 . \leqslant \vee 0$. & $\varepsilon$ & بعدي & \\
\hline \multirow{2}{*}{ دال عند ا ... } & \multirow{2}{*}{ rV.TT } & $1.7 \wedge r \leq 9$ & $0 . v \ldots$ & $\varepsilon$ & قبلي & \multirow{2}{*}{ أداب السلوك } \\
\hline & & $1 . v r 4 \leq 9$ & $1 \leq .1 \ldots$ & $\varepsilon$. & بعدي & \\
\hline \multirow{2}{*}{ دال عند ا ... } & \multirow{2}{*}{$\varepsilon \cdot . \leqslant \wedge$} & I.rKA.r & $\varepsilon .0 \vee 0$. & $\varepsilon \cdot$ & قبلي & \multirow{2}{*}{ المشاركة } \\
\hline & & $\therefore \wedge 1$. & $11.7 \ldots$ & $\varepsilon$. & بعدي & \\
\hline \multirow{2}{*}{ دال عند ا ... } & \multirow{2}{*}{ ON.IT } & $r . \leq \varepsilon 1 \leq 0$ & $17.90 \ldots$ & $\varepsilon \cdot$ & قبلي & \multirow{2}{*}{ مقياس المسئولية } \\
\hline & & E.TYTAY & ET.rTO. & $\varepsilon$. & بعدي & \\
\hline
\end{tabular}

يتضح من جدول (ع ) أنه:

توجد فروق دالة إحصائًاً بين منوسطات درجات أطفال المجموعة التجريبية المستوى الثاني - في التطبيقين القبلي والبعدي لأبعاد ومجموع مقياس المسئولية الإجتماعية لطفل الروضة عند مستوى دلالة ا....، لصالح متوسط درجات الأطفال في التطبيق

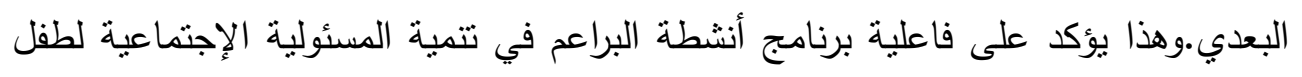
الروضة. تعقيب عام على الفرض الثاني: بعد استعراض نتائج جميع الفروض الفرعية للفرض الأول والذي تتاول نواتج التعلم المنوقعة لطفل الروضة يمكن القول بأنه: 


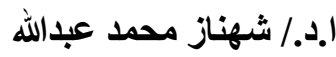

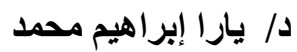

فاعلية أنثطة البراعم في تحقيق نواتج التعلم المتوقعة وتنمية المسئولية الاجتماعية فئية

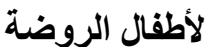

1-إرتفاع درجات المجموعة التجريبية في النطبيق البعدي لرقياس المسئولية

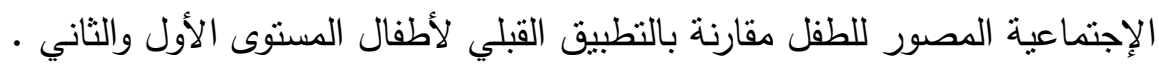

r-تأكيد صحة الفرض الثاني حيث يوجد فروق ذات دلالة إحصائية بين متوسطي درجات أطفال المجموعة التجريبية في التطبيق القبلي والبعدي لمقياس المسئولية الإجتماعية المصور لطفل الروضة لصالح التطبيق البعدي •

r-فاعلية برنامج انتطة البراعم في تتمية المسئولية الإجتماعية لطفل الروضة .

$$
\text { أولاً : حجم الأثر ونسبة الكسب المعدل لبلاك }
$$

وذللك للتعرف على فاعلية أنشطة البراعم في تحقيق نواتج التعلم المنوقعة وتتمية

المسئولية الإجتماعبة لأطفال الروضة، وذلك من خلال حساب المتوسطات القبلية والبعدية لدرجات الأطفال عينة الدراسة في كلًا من مقياس نواتج التعلم، ومقياس المسئولية الإجتماعية لطفل الروضة، ومقياس المسئولية الإجتماعية من وجهة نظر المعلمة، ومقياس المسئولية الإجتماعية من وجهة نظر ولي الأمر، تم حساب نسبة الكسب المعدل لبلاك ."Blake"

\section{ولحساب نسبة الكسب المعدل لـ بلاك ( Blake ) :}

تم استخدام معادلة بلالك لحساب نسبة الكسب المعدل وهى فى الصورة:

$$
\text { نسبة الكسب المعدل = ص- ص-س س- }
$$

س : متوسط درجات الإختبارات القبلى ص: متوسط درجات الإختبارات البعدى . د النهاية العظى للإختبارات . 
المجلة العلمية لكلية رياض الاطفال - جامعة اسيوط

أولًا - الكسب المعدل ومربع ايتا لمقياس نواتج التعلم لطقل الروضة جدول (•): المتوسط الحسابي والانحراف المعياري وقيمة ت وحجم الأثر ومعدل بلاك لأبعاد ومجموع مقياس نواتج التعلم لطقل الروضة (ن = • ؛ )

\begin{tabular}{|c|c|c|c|c|c|c|c|c|}
\hline الدلالة & معدل & مريع & الدلالة & قيمة T & المتوسط & التطبيق & الابعاد & المستوى \\
\hline \multirow{2}{*}{ مرتفع } & \multirow{2}{*}{$1 . r}$. & \multirow{2}{*}{.90} & \multirow{2}{*}{ دالة عند ا ... } & \multirow{2}{*}{ YV..T } & $9.10 \ldots$ & قبلي & \multirow{2}{*}{ النمو الجسمي الحركي } & \multirow{24}{*}{ 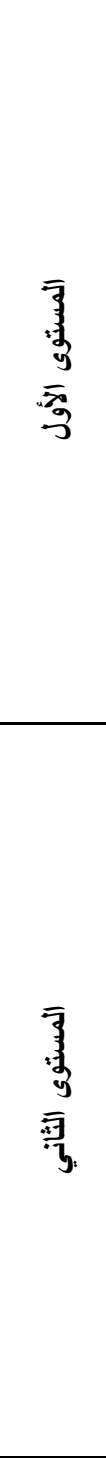 } \\
\hline & & & & & r.vo.. & بعدي & & \\
\hline \multirow{2}{*}{ متوسط } & \multirow{2}{*}{$.7 \leq$} & \multirow{2}{*}{$\cdot \wedge$} & \multirow{2}{*}{ دالة عند •.. } & \multirow{2}{*}{ Ir.rq } & v..vo. & قبلي & \multirow{2}{*}{ النمو الاجتماعي } & \\
\hline & & & & & Ir..vo. & بعدي & & \\
\hline \multirow{2}{*}{ متوسط } & \multirow{2}{*}{$1 . \cdot v$} & \multirow{2}{*}{$.9 \leq$} & \multirow{2}{*}{ دالة عند ا ... } & \multirow{2}{*}{ r $\varepsilon . \varepsilon}$. & $\varepsilon . \wedge 0 \ldots$ & قبلي & \multirow{2}{*}{ أساليب التعليم والتعليم } & \\
\hline & & & & & $1 \varepsilon \ldots \times 0$. & بعدي & & \\
\hline \multirow{2}{*}{ مرتفع } & \multirow{2}{*}{$1 . r$} & \multirow{2}{*}{.94} & \multirow{2}{*}{ دالة عند ا +.. . } & \multirow{2}{*}{ Yr.TV } & V.Avo. & قبلي & \multirow{2}{*}{ والتواصل } & \\
\hline & & & & & $19.0 \ldots$ & بعدي & & \\
\hline \multirow{2}{*}{ متوسط } & \multirow{2}{*}{$1 \ldots$} & \multirow{2}{*}{.911} & \multirow{2}{*}{ دالة عند ا +.. • } & \multirow{2}{*}{$\varepsilon \cdot . r$} & $1 \cdot \ldots$ ro. & قبلي & \multirow{2}{*}{ الوعي والمعرفة العامة } & \\
\hline & & & & & rı.^०... & بعدي & & \\
\hline \multirow{2}{*}{ متوسط } & $1 \ldots$ & $.9 V$ & دالة عند 1.... & ro.00 & rq.vo.. & قبلي & مقاس نماتح التعلى & \\
\hline & & & داله علد ا ••" & & $90.7 \times 0$. & بعدي & معيس سواسج اسعلم & \\
\hline & $1.7 \varepsilon$ & .91 & (1) & $\leqslant r \leqslant$ & $1 \cdot .7111$ & قبلي & & \\
\hline مربقع & 1.12 & .71 & داله علد ا ••” & $21 \cdot+2$ & $r . . .$. & بعدي & & \\
\hline مiت & 180 & 91 & (1) & sq gr & $\varepsilon .90 \leqslant 0$ & قبلي & النمو الاجتماعي & \\
\hline مرتع & & & 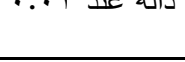 & & $r \ldots \ldots$ & بعدي & الوجداني & \\
\hline & $1, V^{2}$ & 99 & L & Q & צחדזיט & قبلي & & \\
\hline مرثقع & $1 . V$ &. .99 & داله عند ا •.. & $00 . V T$ & 19.9 .91 & بعدي & اسم & \\
\hline مر تفع & $1.7 \mathrm{~V}$ & .91 & دالة عند ا ... . & $\leqslant 7.0$ & $V . \Sigma V V T$ & قبلي & اللغة & \\
\hline مرسع & & & & & $r \leq . V \cdot \leq 0$ & بعدي & والتواصل & \\
\hline & 1.7. & .99 & دالة عند ( ... . & $0 \wedge . \leqslant$. & 14.1091 & قبلي & مقاس نماتح التهلم & \\
\hline مرنقع & 1.1. & .079 & داله عند ا •.. & $0 \mathrm{A.z・}$ & rᄉ.ร.91 & بعدي & معياس سواسج السعم & \\
\hline مرتفع & 1.77 &. .99 & دالة عند ا .... & V^. . 9 & E. .rYVT & قبلي & مقتاس نواتج التعلد & \\
\hline من & & & & & ITr.VV & بعدي & & \\
\hline
\end{tabular}


ا.د./ شهناز محمد عبدالله

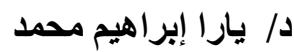

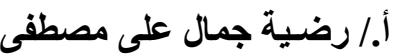

فاعلية أنشطة البراعم في تحقيق نواتج التعلم المتوقعة وتنمية المسئولية الاجتماعية فئية لأطفال الروضة ولميه الرانة

\section{يتضح من جدول (0) ما يلي:}

- قيمة حجم الأثز مرتفعة للمقياس المتدرج لنواتج التعلم لطفل الروضة وأبعاده الفرعية في المستوبين الأول والثاني، وذلك يؤكد استمرارية البرنامج في تأثيره على

الأطفال.

- معدل بلاك للمقياس المتدرج لنواتج التعلم لطفل الروضة وأبعاده الفرعية في المستوي الأول متوسط فهو أصغر من النسبة التي حددها بلاك (r. ().

ـ - معدل بلاك لمقياس نواتج التعلم لطفل الروضة وأبعاده الفرعية في المستوي الثاني مرتفع فهو أكبر من النسبة التي حددها بلاك (Y. (Y) مما يؤكد فعالية البرنامج المقترح فى تحقيق نواتج التعلم المتوقعة لطفل الروضة في المرحلة العمرية من (ع-7 سنوات ) وفقًا لما حددته وزارة التربية والتعليم في وثثقة المعايير القومية ل ل رياض الأطفال

ثانيًا - الكسب المعدل ومريع ايتا لمقياس المسئولية الإجتماعية لطقل الروضة: جدول (†): المتوسط الحسابي والانحراف المعياري وقيمة ت وحجم الأثز ومعدل بلاك لأبعاد ومجموع مقياس المسئولية الإجتماعية لطقل الروضة (ن = ؛ )

\begin{tabular}{|c|c|c|c|c|c|c|c|c|}
\hline الدلالة & معلاك & إيتا & الدلالة & قيمة T & الحسابي & التطبيق & الابعاد & المستوى \\
\hline \multirow{2}{*}{ متوسط } & \multirow{2}{*}{.$\wedge V$} & \multirow{2}{*}{.94} & \multirow{2}{*}{ دالة عند } & \multirow{2}{*}{ rT.IT } & V.OVo. & قبلي & \multirow{2}{*}{ الإعتماد على } & \multirow{9}{*}{ 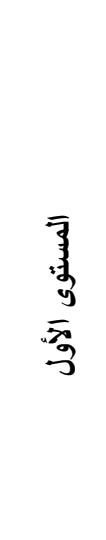 } \\
\hline & & & & & IE.KYO. & بعدي & & \\
\hline \multirow{2}{*}{ متوسط } & \multirow{2}{*}{. .91} & \multirow{2}{*}{.94} & \multirow{2}{*}{ دالة عند } & \multirow{2}{*}{ rr.00 } & $7.90 \ldots$ & قبلي & \multirow{2}{*}{ أداب السلوك } & \\
\hline & & & & & Ir.r... & بعدي & & \\
\hline \multirow{2}{*}{ متوسط } & \multirow{2}{*}{. .91} & \multirow{2}{*}{.94} & \multirow{2}{*}{ دالة عند } & \multirow{2}{*}{$r \cdot . V \leqslant$} & $0 . r \ldots$ & قبلي & \multirow{2}{*}{ المشاركة } & \\
\hline & & & & & $9 . \leqslant 0 \ldots$ & بعدي & & \\
\hline \multirow{3}{*}{ متوسط } & \multirow{3}{*}{. .91} & \multirow{3}{*}{$.9 \mathrm{~V}$} & \multirow{3}{*}{ دالة عند } & \multirow{3}{*}{ rV.OV } & $19.7 \times 0$. & قبلي & \multirow{3}{*}{ الإجسئولية } & \\
\hline & & & & & ro.svo. & & & \\
\hline & & & & & & بعدي & & \\
\hline
\end{tabular}


المجلة العلمية لكلية رياض الاطفال - جامعة اسيوط

\begin{tabular}{|c|c|c|c|c|c|c|c|c|}
\hline الدلائة & معلاك & مريع & الدلائة & قيمة T & الحسابي & التطبيق & الابعاد & المستوى \\
\hline \multirow{2}{*}{ مرتفع } & \multirow{2}{*}{ I.r } & \multirow{2}{*}{. .97} & \multirow{2}{*}{ دالة عند } & \multirow{2}{*}{$r \wedge .9 \wedge$} & $7.7 \times 0$. & قبلي & \multirow{2}{*}{ الإعتماد على } & \multirow{8}{*}{$\begin{array}{l}\overline{3} \\
3 \\
3 \\
\sqrt[3]{3} \\
3\end{array}$} \\
\hline & & & & & $17 . \leqslant \vee 0$. & بعدي & & \\
\hline \multirow{2}{*}{ مرتفع } & \multirow{2}{*}{$1 . \pi \varepsilon$} & \multirow{2}{*}{. $.9 V$} & \multirow{2}{*}{ دالة عند } & \multirow{2}{*}{ rV.Tt } & $0 . v \ldots$ & قبلي & \multirow{2}{*}{ أداب السلوك } & \\
\hline & & & & & $1 \leq .1 \ldots$ & بعدي & & \\
\hline \multirow{2}{*}{ مرتفع } & \multirow{2}{*}{1.04} & \multirow{2}{*}{. .91} & \multirow{2}{*}{ دالة عند } & \multirow{2}{*}{$\varepsilon \cdot . \leqslant \wedge$} & E.0vo. & قبلي & \multirow{2}{*}{ المشاركة } & \\
\hline & & & & & $11.7 \ldots$ & بعدي & & \\
\hline \multirow[b]{2}{*}{ مرتفع } & \multirow[b]{2}{*}{$1 . r 0$} & \multirow[b]{2}{*}{. .99} & \multirow{2}{*}{ دالة عند } & \multirow[b]{2}{*}{$0 \wedge .1 Y$} & $17.90 \ldots$ & قبلي & \multirow{2}{*}{ الإجتئولية } & \\
\hline & & & & & $\varepsilon$ Y.MrO. & بعدي & & \\
\hline
\end{tabular}

\section{يتضح من جدول (؟) ما يلي:}

- ميمة حجم الأثر مرتفعة لمقياس المسئولية الإجتماعية لطفل الروضة وأبعاده الفرعية في المستويين الأول والثاني، وذلك يؤكد استمرارية البرنامج في تأثثره على الأطفال. - معدل بلاك لمقياس المسئولية الإجتماعية لطفل الروضة وأبعاده الفرعية في المستوي الأول متوسط فهو أصغر من النسبة التي حددها بلاك (؟. (1). - معدل بلادك لمقياس المسئولية الإجتماعية لطفل الروضة وأبعاده الفرعية في

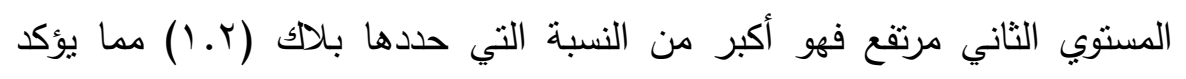
فعالية البرنامج المقترح فى تنمية المسئولية الإجتماعية لطفل الروضة فئة في المرحلة

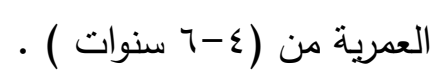

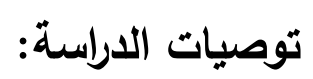

في إطار ما توصلت إليه الدراسة الحالية من نتائج يمكن طرح بعض التوصيات التالية: - تدريب معلمات رياض الأطفال على كيفية تتفيذ أنشطة البراعم مع الأطفال لما

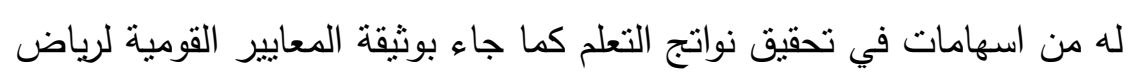
الأطفال والمساهة في تفعيل منهج "حقي ألعب واتعلم وأبتكر". 
ا.د./ شهناز محمد عبدالله

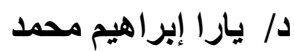

- متابعة تتفيذ أنشطة الكثافة في المراحل التعليمية اللاحقة لما لها من ثأثثير في تتمية المسئولية الإجتماعية لاى الطفل المواطن •

- إجراء العديد من الدراسات التي تهنم بتكوين المواطن الصالح الذي هو هدف

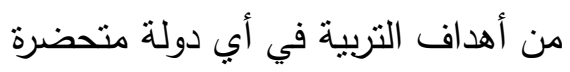

- عدم التركيز على عمليات القراءة والكتابة بشكل رئيسي والتركيز الأكبر يكون على تكوين المواطن الصالح المنتمي لوطنه المتحمل لمسئوليته الإجتماعية

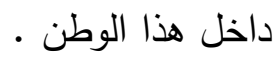

\section{بحوث مقترحة:}

في ضوء نتائج الدراسة الحالية وتوصياتها فإن الباحثة تقترح إجراء البحوث التالية: - فاعلية أنشطة البراعم في إكساب طفل الروضة المفاهيم اللغوية والرياضية والعلمية وذلك وفقًا لوثثقة المعايير القومية لرياض الأطفال.

- فاعلية أنشطة البراعم في نتمية القيم الأخلاقية لطفل الروضة في ضوء المعايير

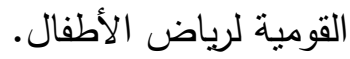

- فاعلية أنشطة البراعم في علاج بعض المشكلات السلوكية لدى أطفال الروضة. - دراسة العلاقة بين نمو المسئولية الإجتماعية لأطفال الروضة والمستوى الثقافي والإجتماعي والإقتصادي للأسرة .

- إعداد برنامج تدريبي لأولياء الأمور لتتمية الوعي السياسي والمسئولية الإجتماعية لأطفال الروضة.

- فاعلية القصة الحركية في إكساب بعض المفاهيم المرنبطة بالممارسات الإجتماعية لأطفال الروضة. 


\section{المراجع}

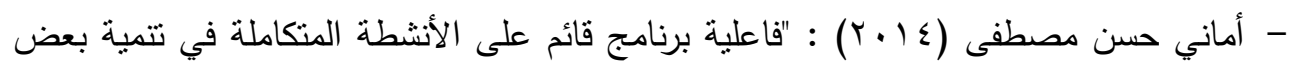

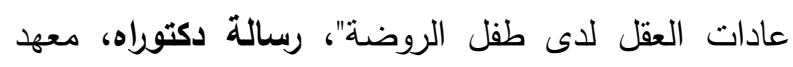

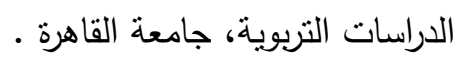

- أماني عبد المنعم زكي البيار (ع) (ب) :" برنامج لتتمية بعض المفاهيم الثاريخية في ضوء

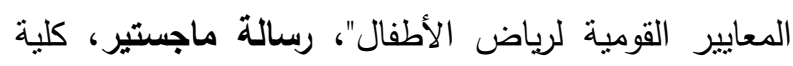

رياض الأطفال، جامعة القاهرة.

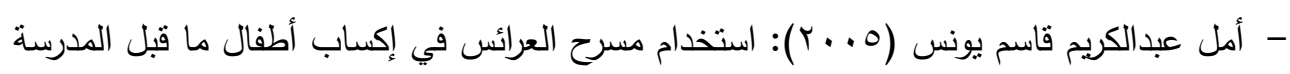

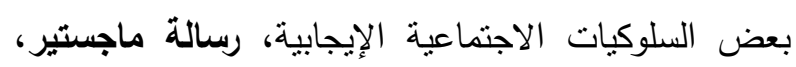

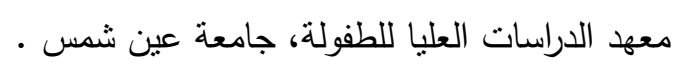

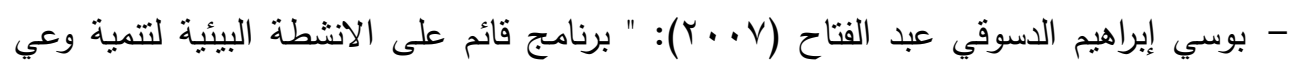
أطفال الرياض ببعض مشكلات تلوث البيئة "، رسائة

ماجستير، كلية التربية، جامعة طنطا.

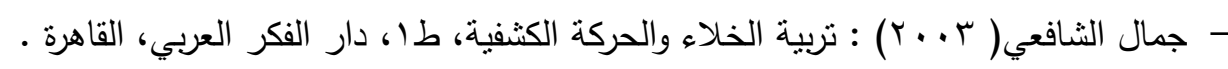
- حسنية غنيمي عبد المقصود (•(ب) : المسئولية الاجتماعية لطفل ما قبل الددرسة : دليل عمل، دار الفكر العربي، القاهرة .

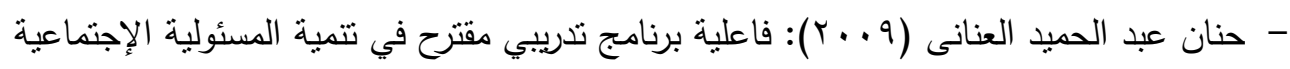

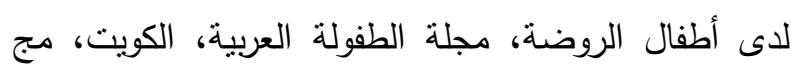

$$
\text { r r r (l) }
$$

- رشاد عبد العزيز موسى (r . . rم ) :" الاتجاهات الوالدية وعلاقتها بمفهوم الذات لدى المراهقين

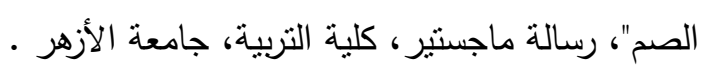

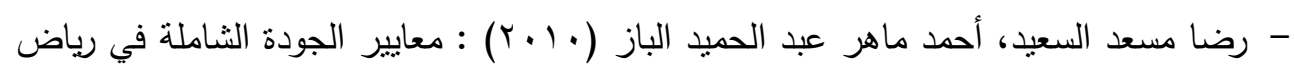

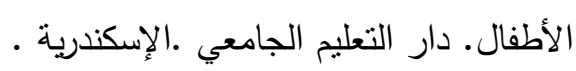


ا.د./ شهناز محمد عبدالله

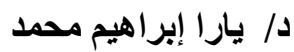

- رضا مسعد احمد (11 (Y): دور الأنشطة الثقافية فى تتمية إنتماء الطفل لروضته، مجلة كلية

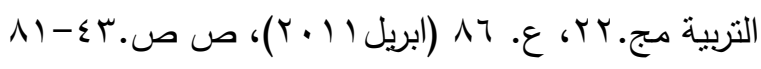

- رنا علاء الدين عبد المنعم علي (10 + ب):" برنامج متحفي لتتمية الوعي الحضاري لدى أطفال الروضة في ضوء المعايير القومية لرياض الأطفال" • رسالة

ماجستير منشورة، كلية رياض الأطفال، جامعة القاهرة .

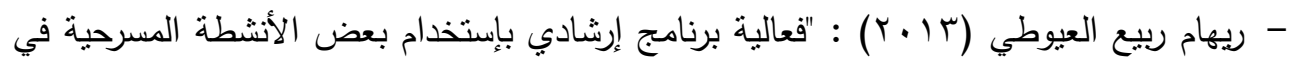

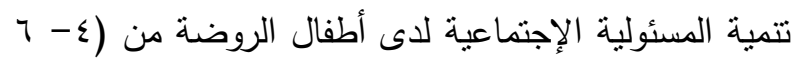
سنوات )" رسالة دكتوراه، مجلة كلية رياض الأطفال،جامعة الإهية

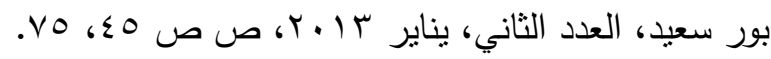
- سيد أحمد عثمان (7/91) : المسئولية الاجتماعية والثخصية المسلمة , مكتبة الأنجلو المصرية، القاهرة .

- عزة علي محمود عبد الرحيم (ع ( • ) :" فاعلية برنامج باستخدام بعض الاستراتيجيات التعليمية

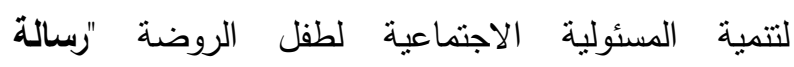
ماجستير، كلية رياض الأطفال، جامعة القاهرة .

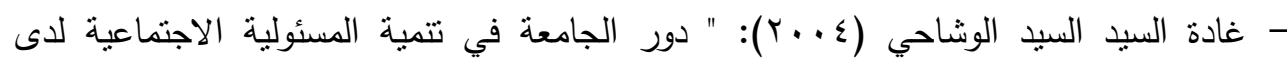
طلابها (دراسة ميدانية)"، رسالة دكتوراه،كلية التربية، جامعة فيهة

$$
\text { أسيوط }
$$

- فرحان أبو زيد جابر (ع . Y): " تقويم النشاط الكثفي للمرحلة الإعدادية بنين بمحافظة أسيوط"، رسالة ماجستير منشورة، كلية التربية الرياضية، جامعة

$$
\text { أسيوط. }
$$

- كمال رجب سليمان(q . . ץ): الكثافة تهذيب للنفس، ط ا، دارالوفاء لدنيا الطباعة والنشر،

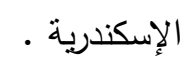

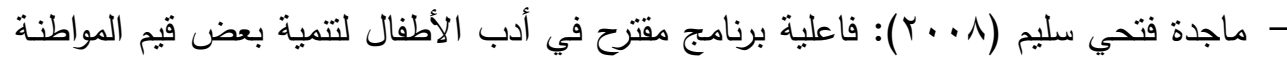

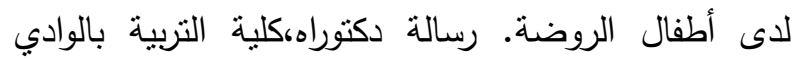

$$
\text { الجديد، جامعة أسيوط. }
$$




\section{المجلة العلمية لكلية رياض الاطفال - جامعة اسيوط}

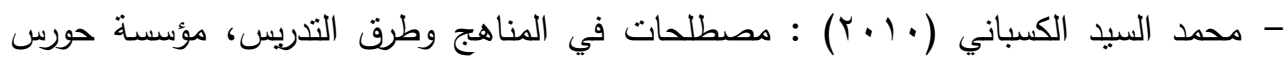
الدولية الإسكندرية إسية

- محمد سلمان مسلم ضحيك (ع . . r) :" القيم المتضمنة في سلوكيات قادة النشاط الكثفي في مدارس محافظات غزة وعلاقتها بالاتزان الانفعالي "، رسالة

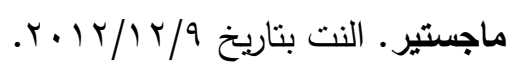

- محمود نسيم، عبد الحافظ عبد الله (T . . r): دليل قادة البراعم، اتحاد الكثافة والمرشدات، القاهرة.

- مرفت سيد مدني (Y I ـ Y) : فاعلية برنامج مقترح لإكساب طفل الروضة قيم المواطنة والانتماء

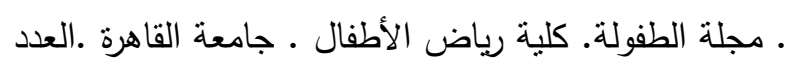

$$
\text { الثاني عثر }
$$

- مليكة كريكرة(^ . ㄷ) :"التربية الكثفية والتنشئة الاجتماعية للطفل"، رسالة ماجستير، جامعة

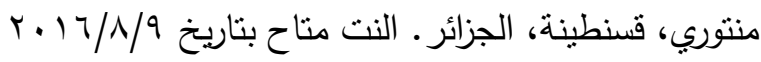

- منى جابر محمد رضوان: برنامج تدريبي في تتمية بعض المهارات الحياتية لأطفال الروضة،

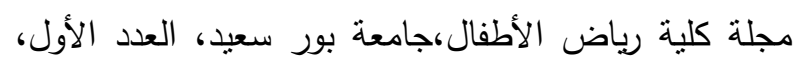

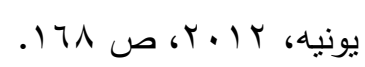

- منى ناجي محمد مصطفى زيدان (ع ( ب):" برنامج لتتمية التسامح لدى طفل الروضة في

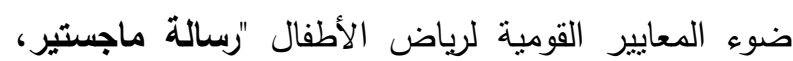

كلية رياض الأطفال، جامعة القاهرة .

- مها صلاح الدين محمد ( 0. . ب): إسهامات الأنشطة التربوية برياض الأطفال في تتمية طفل الروضة (دراسة تقويمية) مجلة مستقبل التربية العربية، العددVr، المركز العربي للتعليم والتتمية، القاهرة، أبريل

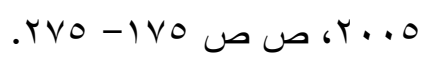

- نورا رمضان عبد الحميد محمود (T/ (Y) : " برنامج أنشطة متكاملة لتمية مفاهيم الصحة

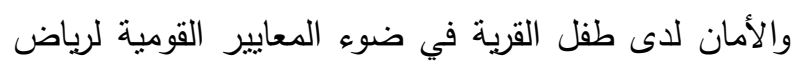


ا.د./ شهناز محمد عبدالله

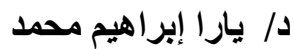

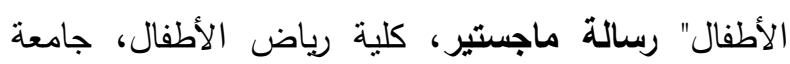

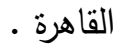

- هشام أحمد عبد الغني، نجلاء مجد النحاس(1 (1 + )، برنامج أنشطة مقترح قائم على الخبرة المتكاملة لإكساب أطفال الروضة المفاهيم الجغرافية الأساسية في المنهج المطور لرياض الأطفال، مجلة كلية

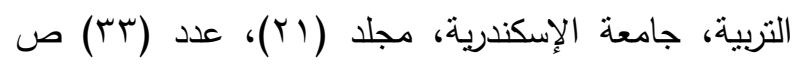

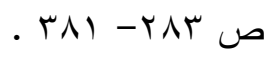

- هشام نبيل عبد الرؤف عبد العزيز (r ( ب) : "العلاقة بين التوعية بالحقوق والحربات المدنية

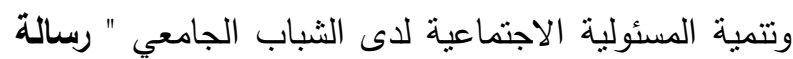
ماجستير، كلية الخدمة الاجتماعية، جامعة أسيوط.

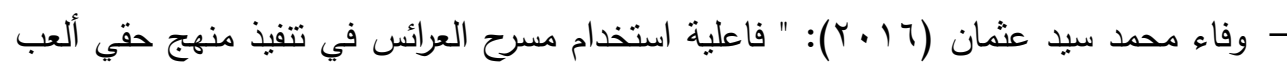
وأتعلم وأبتكر على تتمية بعض المفاهيم الاجتماعية والقيم

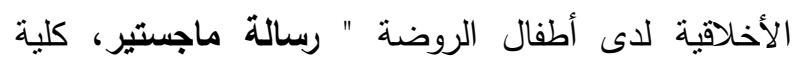

$$
\text { التربية، جامعة سوهاج الاجه ل }
$$

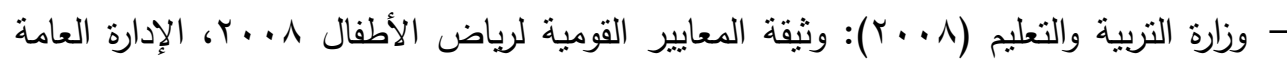

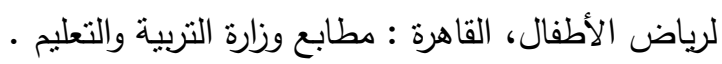

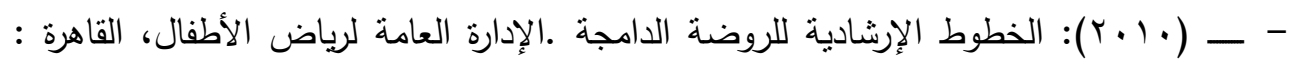

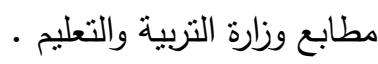

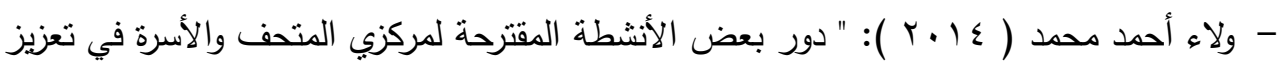
الانتماء وأثره على السلوك الانسحابي لطفل الروضة .رسالة

$$
\text { ماجستير، كلية التربية، جامعة أسيوط واتئره }
$$

- يوسف عبد الله الصغير(乏) (Y): دور بعض المؤسسات التربوية في غرس المسئولية الاجتماعية لدى الطفل في ضوء النموذج الإسلامي، دراسة

تحليلية ـ رسالة ماجستير، كلية التربية، جامعة أسيوط . 


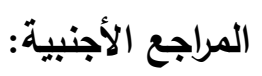

- Blasi,O(2000): An Activities Hand book For Teachers Of Preschool and Curriculum Content, Journal Of Young Children, Vol(86),No(2),July 2000,Pp,95-113 .

- Dic Riley.(2000):Integrating Civi Falu into the Classroom reaching Prekgoct,Vol31 Lisse2,P8.

- Galton,M.(2004):Change in Patterns To Teacher instruction in Preschool. British Educational Research Journal,25.(1),23-37 .

- Grade,A.(2002): The Relationship Between Educational Values and Songs of Children in The Preschool .Journal of Childhood Education ,Vol.(97),No.(2),April 2002, Pp.14-26.

- Herrite,P.(2000):Music Curriculum For Kinder garten , Journal of Music Therapy, vol(24).No.(2),P.68-77.

- Kim, S.,(2008): Teacher -Child interactions in voluntary prekindergarten programs in child care settings: A critical analysis of barriers and facilitations. Ph.D. thesis, University of Florida

- Maria Z.(2001): Play Social Interaction and Motor Development: Practical Activities For Preschool With Visual Impairments. Prono University.

- Mellor, Kenneedy \& GreenWood. (2003): Learning and working now Long.Kindergarten,www.eiv.ced.orgp/pdfs/Scopev2. pdf. 